\title{
MODEL RECONSTRUCTION OF THE VEGETATION COVER OF THE SOUTH OF THE WEST SIBERIAN PLAIN FROM THE LATE PALEOLITHIC PERIOD UNTIL THE LATE XIX CENTURY
}

\author{
M. A. Kharitonenkov \\ Center for Problems of Ecology and Productivity of Forests of the Russian Academy of Sciences (CEPF), \\ 84/32 Profsoyuznaya st., Moscow, 117485, Russia \\ E-mail:kharitonenkov.ma@gmail.com
}

\section{МОДЕЛЬНАЯ РЕКОНСТРУКЦИЯ РАСТИТЕЛЬНОГО ПОКРОВА ЮГА ЗАПАДНО-СИБИРСКОЙ РАВНИНЫ С ПОЗДНЕГО ПАЛЕОЛИТА ДО КОНЦА ХІХ ВЕКА}

\author{
М. А. Харитоненков \\ Центр по проблемам экологии и продуктивности лесов РАН, Россия, 117485, Москва, ул. Профсоюзная, 84/32 \\ E-mail: kharitonenkov.ma@gmail.com
}

Abstract. Model reconstruction of vegetation cover of the south of the West Siberian Plain from the late Pleistocene to the modern era has been carried out on the basis of the associated chronological analysis of paleontological, archaeological and paleoclimate data. We have determined the starting point of active vegetation transformation in the south of the West Siberian Plain as a result of tradition-bound exploitation of natural resources. Periods of maximum anthropogenic load - peak and relative recession - on vegetation cover, acting as a further determinant factor, have been determined in this study for the first time. Comprehensive analysis and new understanding of palynological, paleozoological, archaeological and paleoclimate data in terms of theoretical synecology confirmed the notions on the determinant role of the anthropogenic factor in the transformation of the Pleistocene forest-meadow-steppe vegetation into contemporary communities of the southern taiga, the subtaiga and the forest-steppe of the West Siberian Plain.

Key words: vegetation cover, West Siberian Plain, tradition-bound exploitation of natural resources, Pleistocene, Holocene, palynological analysis.

For citation: Kharitonenkov M.A. Model reconstruction of the vegetation cover of the south of the West Siberian Plain from the late paleolithic period until the late xix century. Russian Journal of Ecosystem Ecology. 2016;1(2). Available from: https://doi.org/10.21685/2500-0578-2016-2-2

Аннотация. На основе сопряженного хронологического анализа палеонтологических, археологических и палеоклиматических данных проведена модельная реконструкция растительного покрова юга ЗападноСибирской равнины с позднего плейстоцена до современности. Определено время начала активного преобразования растительности на юге Западно-Сибирской равнины в результате традиционного природопользования. Впервые выделены и разносторонне обоснованы периоды максимальной антропогенной нагрузки на растительный покров, определявшие его дальнейшее состояние, а также периоды относительного спада нагрузки. Комплексный анализ и переосмысление с позиций теоретической синэкологии палинологических, палеозоологических, археологических и палеоклиматических данных подтвердили представления об определяющей роли антропогенного фактора в трансформации плейстоценовой лесо-лугово-степной растительности в современные сообщества южной тайги, подтайги и лесостепи Западно-Сибирской равнины.

Ключевые слова: растительный покров, Западно-Сибирская равнина, традиционное природопользование, плейстоцен, голоцен, палинологический анализ.

\section{Importance of the Subject of Study}

The peculiarity of the contemporary stage of the reconstruction of vegetation cover of large natural regions consists in the recognition of the necessity to detect and adequately evaluate the leading factors of vegetation formation at different times and, first and foremost, the anthropogenic factor. Such interdisciplinary research is necessary to gain full knowledge of the dynamic processes both in today's vegetation cover and the vegetation cover of the past. However, until recently the issue of impact exercised by certain factors on the centurieslong dynamics of the vegetation cover for such a large region in Eurasia as the West Siberian Plain has not been examined sufficiently. This is ex- 
plained by weak development of agreed and joint paleobotanical, paleozoological and archaeological research as well as by the absence of an integral methodological foundation for such reconstructions until recently.

For the south of the West Siberian Plain, ample volume of data necessary for historical-ecological reconstructions has been accumulated over many years of paleonological, paleozoological and archaeological research. Theoretical notions regarding the principles of natural eco-system cover organisation, developed in the last decades, allow new description of the contribution made by different factors into the Pleistocene-Holocene dynamic of communities in the south of the West Siberian Plain, on the basis of these data.

Aim of the article: to perform, on the basis of comparisons between archaeological, paleoclimate and paleontological data, a model reconstruction of the vegetation cover of the south of the West Siberian Plain, evaluating the contribution made by the anthropogenic factor into the formation and development of contemporary types of vegetation in the epoch of tradition-bound exploitation of natural resources (the Paleolithic period - the end of the XIX century).

\section{Methodology and Methods}

\section{Methodology of the present research is based on the following notions.}

1. Notion of the determinant role of the tradition-based exploitation of natural resources in the transformation of the eco-system cover. Proposed reconstructions are based on the anthropobiotic concept [1], where literature devoted to the impact of the exploitation of natural resources on the biota and the climate was accumulated [2-10 et al.].

Examination of this literature allowed to put forward a hypothesis on human activities prevailing in the dynamic of today's landscapes of the south of the West Siberian Plain, starting from the late Pleistocene.

It should be emphasized that a significant share of the historical-ecological reconstructions conducted for the West Siberia [11-15], was created within the framework of the climatic (zonal bioclimatic) concept [16]. The abovementioned concept postulates a strictly determined link between the changes in the vegetation cover reconstructed using palynological data and climate changes. Climate changes in turn are reconstructed on the basis of the changes in vegetation cover.

Conducted comprehensive research demonstrated [17] that there is no direct unequivocal link between the climate and the biota. The correlation between the climate and the spread and abundance of plants and animals (flora and fauna) is very complex and is refracted through the prism of inter-species and intra-species relations. Borders of plant habitats lie in places where the competitive capacity of the species decreases so much that the species is no longer capable of successfully developing due to various conditions of the environment. Borders of habitats do not have a direct link with the climate even in those cases when they coincide with any of the isolines of climatic variables [18].

Moreover, the very possibility to actually tie sporo-pollen spectrum to any or even a group of simple climatic elements is dubious. The link between biogeocenosis and landscapes with the climate manifests itself through complex comprehensive (integral) indicators, which remain intact despite rather considerable changes of simple climatic elements [19].

All organisms respond to the climate change by intraspecies morpho-physiological adaptive variability. Moreover, plants compensate this by means of biotope change, and in so doing retain relatively consistent hydrothermic conditions of the habitat [17].

Outward morphological homogeneity of the species masks their genetic polymorphism [20]. Thanks to this, species represent complex systems of co-subordinate taxonomic units: biotypes, biological groups and eco-elements that differ through small inherited specificities in morphology, pace of development and tolerance. When in new conditions of existence, such complex systems are differentiated into ecotypes and sub-species over several generations, under the influence of the natural selection [21].

Furthermore, it has been demonstrated that formed vegetation cover is capable of changing the climate, sustaining optimal habitat environment and contributing to the progression of species into conditions unacceptable in terms of abiotic indicators [9].

Our research certainly has taken into consideration paleoclimatic specificities of the studied area. However, in contrast to adherents of the zonalbioclimatic concept, it used climate constructions, based on the data relatively independent of the biota, namely - the results of isotopic analysis of ice $[22,23]$.

The present article has put forward the following assumption as a working hypothesis: climate changes did not fully determine long-period variability of ecosystems, but they did impact the speed of ongoing biotic processes.

2. Notions of the potential ecosystem cover and methods of its model reconstructions performed on concrete areas [24, 7, 25-27]. 
The dynamics of the vegetation cover has been reconstructed on the basis of the analysis of palynological (sporo-pollen) and historical data. The work used published data [28-32] and the results of our own research [33].

Primary data have been extracted from the published works - palynological spectra of sequences, predominantly those of peat deposits as well as soils beneath archaeological monuments. Those have been interpreted on the basis of standard methodology grounded in correlations of reflection of today's vegetation cover by the recent spectra [34]. The published spectra of the southern taiga, subtaiga and forest-steppe valley of the $\mathrm{Ob}^{\prime}$ river peat deposits were used as the recent ones.

Data processing allowed evaluating changes in the amount of forests of the area from the late Pleistocene until the end of the XIX century as well as changes in the species (genus) composition and species richness (genus richness) of trees. At the same time, the level of correlation between the species' pollen share and its actual participation in the forest stand - detected by means of the recent spectra - was consistently taken into account. The amount of forests of the area is determined on the basis of the tree and herb pollen share ratio. Dis- crepancies between pollen productivity of trees of different species (genera) were taken into account. Chronological identification of spectra was carried out on the basis of the dating assigned by the authors. In cases when these were absent, the spectra were dated on the premises of peat accumulation speed calculated for the West Siberian Plain [35].

\section{Volume of Palynological Material}

The asynchronous pollen spectra of 38 palynological sequences of the studied area were analyzed. Palynological data from adjacent areas was brought in for comparison. The vegetation cover was being reconstructed for each sequence within the boundaries of each epoch (Table 1). The most common traits of vegetation changes in the examined historical-geographical areas were identified. Eventually, it was possible to reconstruct the dynamics of the vegetation cover by comparing its changes across different epochs. Historical data on the vegetation were analyzed in search of data which would provide information on the amount of forests in the area and species composition of arboreal plants.

Table 1

Palynological Sequences Used for Reconstruction

\begin{tabular}{|c|c|c|c|c|}
\hline Epoch & $\begin{array}{l}\text { Lower Tobol' } \\
\text { river region }\end{array}$ & $\begin{array}{l}\text { Middle Irtysh' } \\
\text { river region }\end{array}$ & Upper Ob' river region & References \\
\hline 1 & 2 & 3 & 4 & 5 \\
\hline $\begin{array}{l}\text { Paleolithic, } \\
\text { Mesolithic, } \\
\text { Neolithic, } \\
\text { Eneolithic }\end{array}$ & $\begin{array}{l}\text { 2/98; L 1/95; } \\
\text { Cultural proper- } \\
\text { ty site (C.p.s.) } \\
\text { hillfort Belyiy } \\
\text { Yar } 4\end{array}$ & $\begin{array}{l}\text { Aksurka; } \\
\text { Gladilovskiy } \\
\text { Ryam; Katenka; } \\
\text { Chany lake; } \\
\text { C.p.s. Lastochkino } \\
\text { Gnezdo-1; } \\
\text { C.p.s. Mergen lake; } \\
\text { Stanichnyy ryam; } \\
\text { Sfagnovyy Ryam; } \\
\text { Ubinskiy ryam; } \\
\text { Chuvashi; } \\
\text { Sequences in Omsk } \\
\text { Irtysh' river region }\end{array}$ & $\begin{array}{l}\text { Zhukovskiy peat-bog; Belyy } \\
\text { Yar; } \\
\text { Bog Gladkoye; } \\
\text { Tolmachevsko- } \\
\text { Krivodanovskoye; } \\
\text { Peat-bog in Tom river creek; } \\
\text { Kirek lake; } \\
\text { Ovrazhnoye; } \\
\text { Chaginskoye; } \\
\text { Kulymany; } \\
\text { Novo-Uspenka; } \\
\text { Kayakskoye zaymishche; } \\
\text { Beglyanskiy ryam; } \\
\text { Beloye lake (2 sequences); } \\
\text { Mamonovo }\end{array}$ & $\begin{array}{l}\text { Khotinskiy, } 1977 \text { [28]; } \\
\text { Blyakharchuk, } 1989 \text { [29]; } \\
\text { Orlova, } 1990 \text { [30]; } \\
\text { Bolotnyye..., 2001 [31]; } \\
\text { Ryabogina etc., } 2004 \text { [32]; } \\
\text { Levkovskaya,1974 [36]; } \\
\text { Arkhipov, Votakh, } 1980 \text { [37]; } \\
\text { Piavchenko, } 1985 \text { [38]; } \\
\text { Levina, Orlova, } 1993 \text { [39]; } \\
\text { Ryabogina etc., } 2001 \text { [40]; } \\
\text { Yakimov etc., } 2007 \text { [41]; } \\
\text { Zakh, 1997, 1999 [42, 43]; } \\
\text { Ivanov, Ryabogina, 2003 [44]; } \\
\text { Khazina, 2008 [45]; } \\
\text { Bolshanik, } 1998 \text { [46]; } \\
\text { Zykina etc., } 2000[47]\end{array}$ \\
\hline Bronze Age & 2/98; L 1/95 & $\begin{array}{l}\text { Aksurka; } \\
\text { Chany lake; } \\
\text { Stanichnyy ryam; } \\
\text { Sfagnovyy Ryam; } \\
\text { Ubinskiy ryam; } \\
\text { Chuvashi; } \\
\text { Gladilovskiy } \\
\text { Ryam; } \\
\text { Chicha; } \\
\text { Koltyugino }\end{array}$ & $\begin{array}{l}\text { Guskovskiy ryam; } \\
\text { Zhukovskiy peat-bog; } \\
\text { Beloye lake (2 sequences); } \\
\text { Beglyanskiy ryam; } \\
\text { Bog Gladkoye; } \\
\text { Kayakskoye zaymishche; } \\
\text { Ovrazhnoye; } \\
\text { Chaginskoye; } \\
\text { Kulymany; } \\
\text { Novo-Uspenka; } \\
\text { Tolmachevsko- } \\
\text { Krivodanovskoye; } \\
\text { Peat-bog in Tom river creek; }\end{array}$ & $\begin{array}{l}\text { Volkova etc., } 2002 \text { [15]; } \\
\text { Khotinskiy, } 1977 \text { [28]; } \\
\text { Blyakharchuk, } 1989 \text { [29]; } \\
\text { Orlova, } 1990 \text { [30]; } \\
\text { Bolotnyye..., 2001 [31]; } \\
\text { Ryabogina, } 2004 \text { [32]; } \\
\text { Kharitonenkov etc., } 2012 \text { [33] } \\
\text { Ryabogina etc., 2001 [40] }\end{array}$ \\
\hline
\end{tabular}


End of Table 1

\begin{tabular}{|c|c|c|c|c|}
\hline 1 & 2 & 3 & 4 & 5 \\
\hline $\begin{array}{l}\text { Early Iron } \\
\text { Age - } \\
\text { Middle Ages }\end{array}$ & $\begin{array}{l}\text { 2/98; L 1/95; } \\
\text { C.p.s. hillfort } \\
\text { Rafaylovskoye } \\
\text { городище; } \\
\text { C.p.s. } \\
\text { Kolovskoye }\end{array}$ & $\begin{array}{l}\text { Aksurka; } \\
\text { Chany lake; } \\
\text { Sfagnovyy Ryam; } \\
\text { Stanichnyy ryam; } \\
\text { Chuvashi; } \\
\text { Gladilovskiy } \\
\text { Ryam; } \\
\text { Chicha; } \\
\text { Kalininskiy ryam; } \\
\text { Kayly; } \\
\text { Shipunovo; } \\
\text { Koltyugino }\end{array}$ & $\begin{array}{l}\text { Zhukovskiy peat-bog; } \\
\text { Kulymany; } \\
\text { Novo-Uspenka; } \\
\text { Ovrazhnoye; } \\
\text { Peat-bog in Tom river creek; } \\
\text { Beloye lake; } \\
\text { Bog Gladkoye; } \\
\text { Guskovskiy ryam; } \\
\text { Kayakskoye zaymishche; } \\
\text { Suminskoye zaymishche; } \\
\text { Ubinskiy ryam; } \\
\text { Kargapolovo }\end{array}$ & $\begin{array}{l}\text { Khotinskiy, } 1977 \text { [28]; } \\
\text { Blyakharchuk, } 1989 \text { [29]; } \\
\text { Orlova, } 1990 \text { [30]; } \\
\text { Bolotnyye ..., 2001 [31]; } \\
\text { Ryabogina, 2004 [32]; } \\
\text { Kharitonenkov etc., 2012 [33] } \\
\text { Piavchenko, } 1985 \text { [38]; } \\
\text { Khazina, 2008 [45]; }\end{array}$ \\
\hline Modern era & 2/98; L 1/95 & $\begin{array}{l}\text { Aksurka; } \\
\text { Chany lake; } \\
\text { Sfagnovyy Ryam; } \\
\text { Stanichnyy ryam; } \\
\text { Chuvashi; } \\
\text { Gladilovskiy } \\
\text { Ryam; } \\
\text { Chicha; } \\
\text { Kalininskiy ryam; } \\
\text { Kayly; } \\
\text { Shipunovo; } \\
\text { Koltyugino }\end{array}$ & $\begin{array}{l}\text { Zhukovskiy peat-bog; } \\
\text { Kulymany; } \\
\text { Novo-Uspenka; } \\
\text { Ovrazhnoye; } \\
\text { Peat-bog in Tom river creek; } \\
\text { Beloye lake; } \\
\text { Bog Gladkoye; } \\
\text { Guskovskiy ryam; } \\
\text { Kayakskoye zaymishche; } \\
\text { Suminskoye zaymishche; } \\
\text { Ubinskiy ryam; } \\
\text { Kargapolovo }\end{array}$ & $\begin{array}{l}\text { Khotinskiy, } 1977 \text { [28]; } \\
\text { Blyakharchuk, } 1989 \text { [29]; } \\
\text { Orlova, } 1990 \text { [30]; } \\
\text { Bolotnyye ..., 2001 [31]; } \\
\text { Ryabogina, } 2004 \text { [32]; } \\
\text { Kharitonenkov etc., 2012 [33]; } \\
\text { Piavchenko, } 1985 \text { [38]; } \\
\text { Khazina, } 2008 \text { [45] }\end{array}$ \\
\hline
\end{tabular}

\section{Volume of Examined Material (Archaeological and Historical)}

On the basis of the archaeological and historical materials, systems of the population's settlement and human economic activities were reconstructed. Only the published results of archaeological research were used when conducting the present research. The former were used to accumulate data on the peculiarities of the system of settlement and the type of exploitation of natural resources of each archaeological culture. We have collected available information covering all the stationary settlements examined as of today (1875 settlements), which allows carrying out territorial analysis of archaeological cultures when doing the mapping. Overall, 61 archaeological cultures have been analyzed. Historical data chronologically fit into the framework of the last 400 years. From these data we have extracted information that allows tracking down the system of settlement and the peculiarities of the exploitation of natural resources.

The material was collected in three historicalgeographical regions located sublatitudinally in the south of the West Siberian Plain and covering part of today's southern taiga, subtaiga and foreststeppe: 1. Lower Tobol' river region (the Tobol river basin within the Tumen and the northern edge of the Kurgan region.); 2. The Middle Irtysh river region (the Ishim Plain, the west of the Baraba Plain, within the eastern part of the Tumen region and the western part of the Novosibirsk region.); 3. The Upper Ob' river region (its lowland part the part of the $\mathrm{Ob}$ ' river basin to the south of the Chulym river estuary and to the east of the Baraba Plain within the boundaries of the eastern part of the Novosibirsk and the south of the Tomsk regions) [48] (Fig. 1).

The choice of the research area is determined by the necessity to expand the geographical framework of the historical-geographical work started in 2001 for the Russian Plain [7, 24, 49]. Extending this type of research to the whole of the Northern Eurasia forest belt will make it possible to reconstruct the potential vegetation cover of this area and evaluate the contribution of the anthropogenic impacts into the formation of today's Northern Eurasian landscape zonal distribution.

The choice of the territory is determined by the fact that from the archaeological point of view it has been very well examined as well as by the presence of the whole spectrum of tradition-bound exploitation of natural resources in the mentioned period. 


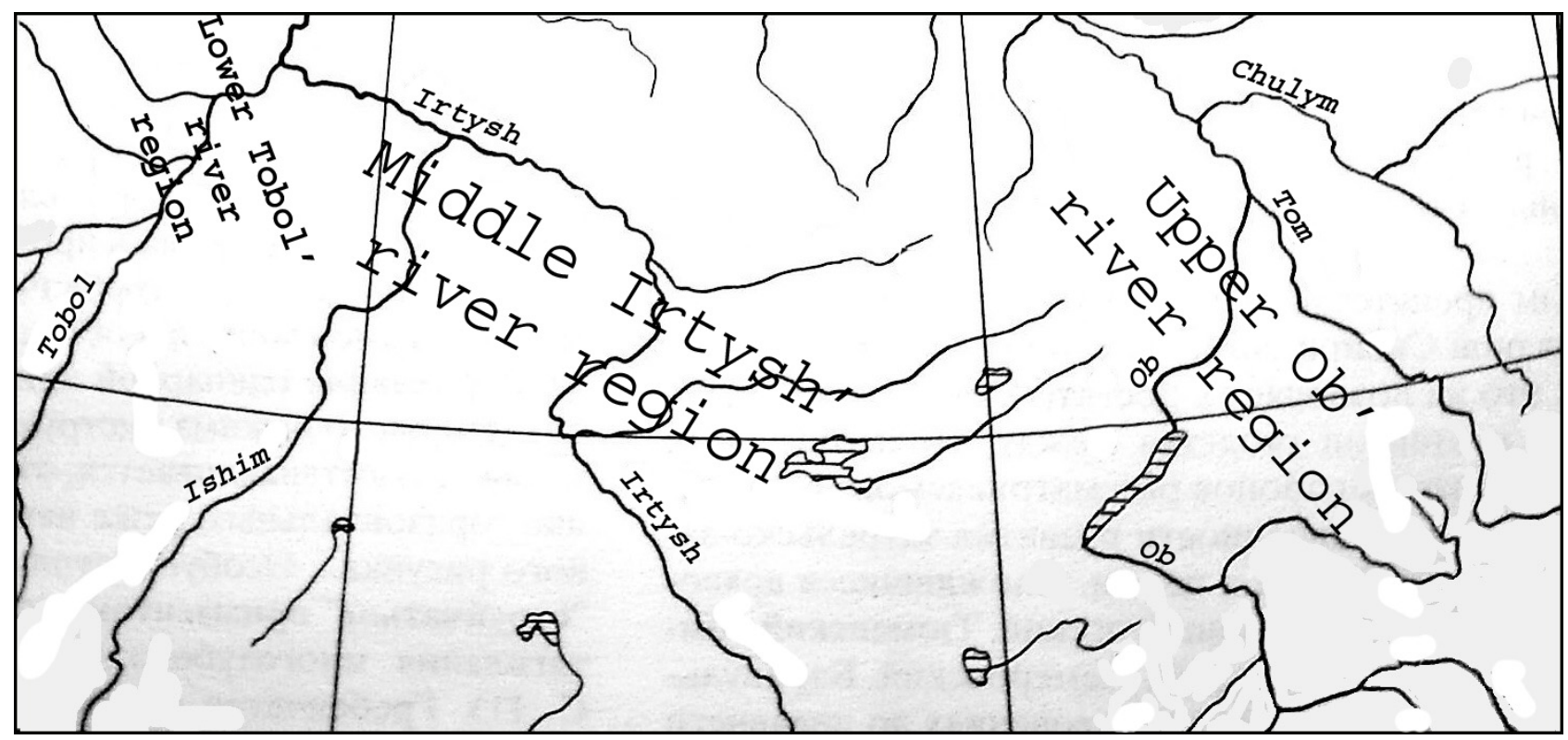

Fig. 1. Historical-geographical division of the studied area of West Siberia (the Neolithic period..., 1996)

\section{Results and Discussion}

Model reconstruction of the pre-anthropogenic appearance of the vegetation cover of the south of the West Siberian Plain.

At the contemporary stage of archaeological research it is considered that the man (more specifically Homo sapiens) began to colonize the West Siberian Plain in the late Pleistocene [50]. Therefore, late-Pleistocene vegetation may be considered as the reference vegetation and starting from this period we can start tracing the impact of human populations on its composition and structure.

In the late Pleistocene the whole of Northern Eurasia had a "hyperzone" that was represented by comprehensive landscapes and joined with it were elements of steppes, meadows, forests and the tundra [51, 52]. In accordance with the key statements of the anthropobiotic concept, key phytophagous species of the megafauna played the major role in formation, wide distribution and long-standing existence of the "hyperzone" communities. Their enormous environmenttransforming impact suppressed the development of arboreal plants on significant surfaces, creating advantages for open herbal communities. In this connection, the vegetation cover in general was characterized by mosaic character and productivity $[49,53,54]$.

\section{Appropriating Economy Epoch (Fig. 2)}

Model Reconstruction of Vegetation Cover. The Paleolithic (Old Stone Age) epoch coincides with the Pleistocene and partly the Holocene divisions of the Quaternary Period.

Reconstruction of the vegetation cover of the late Pleistocene (126000-11700 B.C.) and the
Ancient Holocene ( 11700-10000 B.C.) was carried out as a result of analyzing palynological spectra of 12 sequences in both the examined and the adjacent historical-geographical areas [36, 55-57].

On the basis of the studied spectra of the Kargin interval ( $27000-23000$ B.C.), the Sartan interval (23000-11700 B.C.) of the Pleistocene and the Ancient Holocene we can reconstruct the typical forest-meadow-steppe vegetation of the "hyperzone", in which ample meadow-steppe communities were present along with forest ranges that included the whole set of potential forest-forming species (late-successional - Picea obovata, Pinus sibirica, Abies sibirica, Tilia cordata, Ulmus sp., explerent - Pinus silvestris, Populus tremula, Betula sp., Salix sp., Larix sibirica).

In forest areas explerent tree species played a significant role - such as Betula sect. Albae and Pinus silvestris. In the Sartan interval the forest surfaces were apparently smaller than in the Kargan interval. The share of late-successional tree species was likewise smaller. In the meadowsteppe communities the share of gramineous plants, artemisias and Chenopodiaceae species was more significant than in the Kargan interval. Woodlands in a number of cases could represent heavily bleached wood-meadows dominated by explerent tree species and the meadow-steppe herbaceous cover.

Reconstruction of the vegetation cover of the first half of the Holocene (11700-5000 B.C.) was performed as a result of analyzing palynological spectra of 21 sequences (see Table 1). These spectra reflect vegetation cover dynamics trends common for the whole of the studied area. 


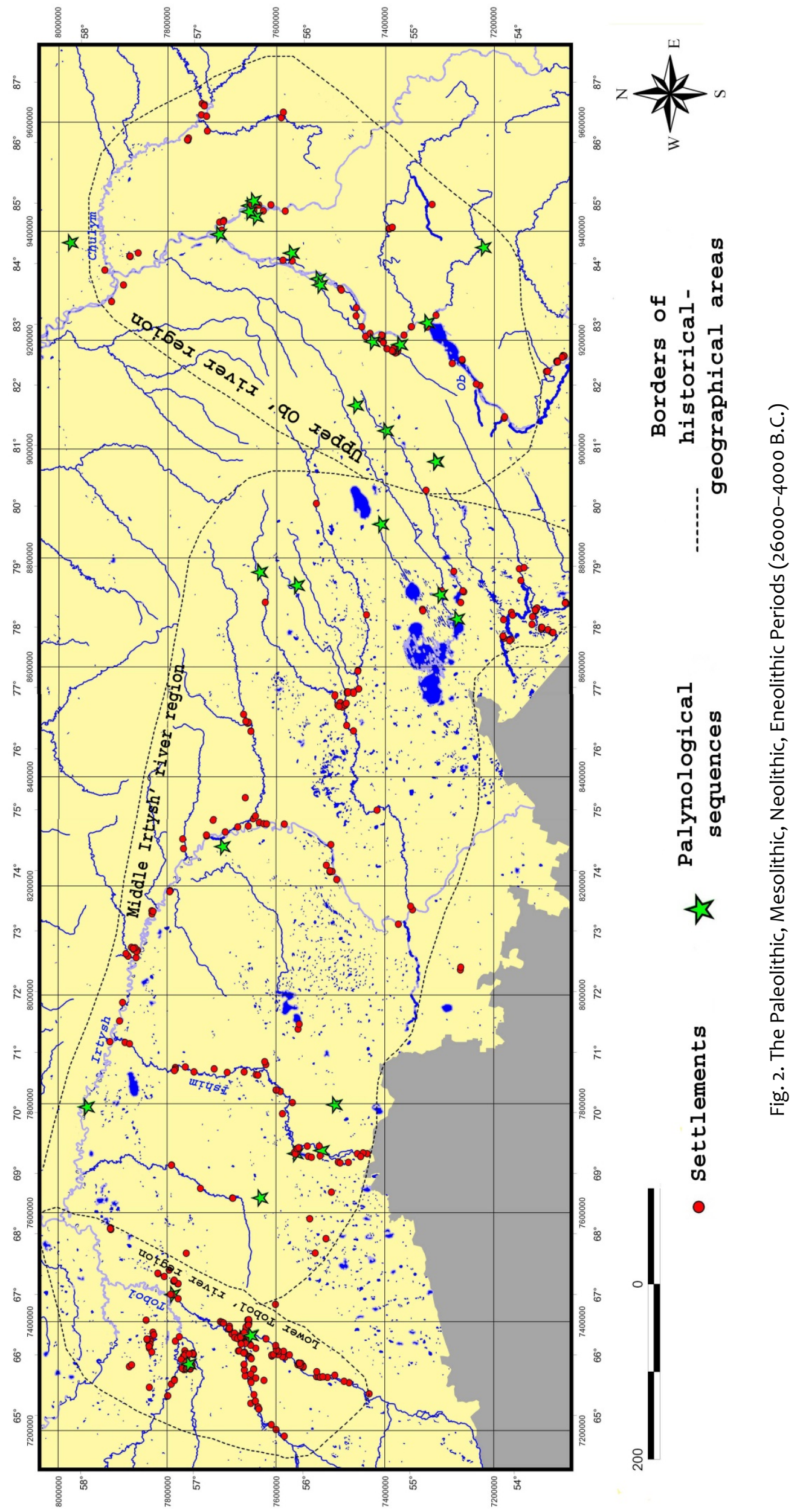


Throughout the Mesolithic period: the Pre-boreal (10000-9000 B.C.) and Boreal (9000-8000 B.C.) periods of the Holocene - the amount of forests in the area gradually increased, while the surface occupied by the meadow-steppe communities decreased. Woodlands were increasing by means of rapidly settling species of birch-trees and pines; at the same time the share of dark-coniferous trees and broadleaved trees of various species was gradually increasing. Nonetheless, the vegetation cover of the analyzed area was represented by different variants of the forest-meadow-steppe complexes.

In the Neolithic period (Atlantic period) (8000-5000 B.C.) slow-paced and patchy afforestation of the territory continued. The nature of the pollen spectra indicates that the uninterrupted forest strip was not yet formed in the regions of today's southern taiga. Forests were considerably thinned or there was a high share of meadow-steppe areas within them. However, the dark-coniferous taiga was being shaped in the neighbouring more northern areas, especially to the north-east, in the Atlantic period $[28,55,58]$ judging by the spectra.

The composition and structure of the vegetation cover of the areas today occupied by the foreststeppe and sub-boreal forests did not differ in general. Judging by the pollen spectra, northern foreststeppe landscapes or heavily thinned forests were predominant. In the forest stand composition, birch tree species and Pinus silvestris played a significant role, presence of dark-coniferous species (the spruce, the fir, and the cedar in particular) was stable as well as that of broadleaved trees. The herbaceous cover was dominated by representatives of steppefied communities: ChenopodioídeaeArtemisiinae and Gramíneae groups.

Reconstruction of the vegetation cover of the studied area for the Eneolithic period (the first half of the Subboreal period - 5000-4000 B.C.) was carried out on the basis of the analysis results covering palynological spectra from 22 sequences (see Table 1).

By looking at the spectra of these sequences, a significant increase in the amount of forests was reconstructed in the Eneolithic period in the studied area, especially in today's sub-boreal forests and the forest-steppe. The meadow-steppe areas were actively covered with pine forests (apparently, along the terraces with light soils) and birch forests (on upland soil). In previously formed woodlands participation of dark-coniferous species (more often the spruce and the cedar, less frequently - the fir) and broad-leaved trees (the elm-tree and the linden) increases. Within the boundaries of today's southern taiga the increased share of darkconiferous species and broadleaves is very distinct, judging by the pollen spectra. In many cases they already accounted for a significant share of the forest stand. However, forests remain thinned as the herbaceous layer exhibited a big share of heliophilous plants. Apparently, they were combined with Gramíneae-mixed grass and herb meadows. The share of birch-tree remained high in the forest stand composition.

Herbivorous megafauna. In the late Pleistocene, 70000-60000 B.C., in the studied area the late mammoth fauna reached its prime [59]. Despite significant climate fluctuations in the late Pleistocene, at this time this area preserved mixed species composition of its fauna complexes (representatives of steppe, tundra, forest-steppe and forest communities). Animals of open and half-open spaces - mammoths, bisons, horses - were predominant both in terms of the number of species and the number of bones in the locations [60,61].

It is believed that with the transition to the Holocene the archaeologically unified mammoth fauna disintegrated due to breached habitats and uncompensated extinction of many species $[62,63]$. The sole indirect proof of this opinion for the studied area is the virtually complete absence of locations of megafauna representatives for the first half of the Holocene as well as the absence of faunal locations of that time generally significant for the analysis [64]. However, it is important to note that throughout the whole of the Pleistocene one can trace uninterrupted development of the line Archidiskodon-Mammuthus, the tribe Ovibovini, genera Bison, Equus. Any change of fauna or any noticeable shift of their boundaries in different climatic periods of the Pleistocene have not been detected [65]. We believe that the absence of findings may be linked not to the disappearance of the largest representatives of the mammoth complex or a sharp change of their habitat, but to the uneven decrease in the population size as well as to the change of the taphocoenosis formation regime.

In accordance with the major statements of the concept of key species, the most unambiguous, albeit indirect, characteristic of the population's presence may consist in proliferation of communities they form. As it has been demonstrated above, in the first half of the Holocene the studied area was dominated by the vegetation that in principle did not differ from the Pleistocene vegetation (its appearance to a large extent was determined by the megafauna activity).

The analysis of the history of the PleistoceneHolocene transformation of habitats of the most crucial and the most mass West Siberia megafauna representatives: the mammoth, the bison, the horse [64, 66-69] allows to assume that the process of mammoth fauna transformation into contemporary faunal complexes did not happen at the turn of the 
Pleistocene and the Holocene, but lasted from the end of the Pleistocene roughly until the middle of the Holocene. The following chronological sequence of the mammoth fauna transformation may be proposed: maximal spread, high species richness and a big population size in the late Pleistocene, a certain decrease in population size of the key megafauna representatives as well as the disappearance of the mammoth itself approximately on the borderline with the Holocene, the continuing gradual fall in the size of populations of large gregarious hoofed mammals from the Pre-boreal until the Atlantic periods within the Holocene.

Peculiarities of human settlement and paleoeconomy. From 25000-24000 B.C. colonization of plain areas of the West Siberia began [50]. It went on in the process of several migration waves. The last one was the most intensive and was linked to the so-called Gravettian episode of Europe that began around 24000 B.C. [70]. The main trait of this stage of the Paleolithic period consists in the large-scale and prolonged expansion of the highlydeveloped population from Central Europe to the east - the population that formed a huge unified historical-cultural community. For the first time in history specialized predominantly mass hunting for the largest megafauna representatives, and first and foremost, the mammoth became the main form of economic activity of these tribes. The Maltinskaya archaeological culture was a local variation of this historical-cultural community in Siberia [71]. Apparently, it was the ancestors of the Maltinskaya culture representatives that continued to develop independently at the final stage of the Paleolithic period as well as the Mesolithic period and the early Neolithic period (10000-5000 B.C.). Seminomadic, and possibly nomadic, hunting, remained the major type of exploitation of natural resources, which can explain relatively small number of open settlements of that time. The prime of cropping pressure at these epochs had to shift (as the size of populations continued to decline) from the mammoth to the bison (as the second biggest gregarious animal kill) and the aurochs, and further on to the horse (as the most numerous species). As the populations of the key species of grazing eco-systems decreased in size, the cropping pressure shifted more to forest species, which was encouraged by further improvement of hunting tools [48].

In the Neolithic period, the autochthonous cultural-historical community of the West Siberian Plain split due to the beginning of new large-scale migrations of the population from the south, first and foremost from the Caspian Sea region and the Aral Sea region. There was a considerable increase in the size of the population, apparently both endemic and foreign [72], which was primarily mani- fested through the increased number of settlements. In the meantime local cultural tendencies started manifesting themselves, which eventually led to the establishment of a raft of Neolithic cultural habitats in West Siberia: Boborykino, Polydenkovo, Sosnovoostrovsk, Kokuisk, Shapkul'sk, Verkhneobsk (Neolithic) cultures [48, 72]. The economy of these cultures continued to be based on semi-nomadic hunting, which is evidenced by the set of tools and the settlement specificity: a great number of short-term seasonal man sites with no traces of permanent dwellings [73, 74].

In the Eneolith period the southern area of the West Siberian Plain was colonized by representatives of Lybaevo, Shapkul'sk, Lipchinsk, Andreevo, Ekaterininsk and Novokuskovo cultures. In the economic orientation of these tribes there is an obvious trend towards decreasing the share of hunting and increasing the share of fishing. In the context of the depletion of game ungulates, fishery was a more stable and reliable source of food procurement than hunting. The indicated changes in the economic activities of tribes resulted in a shift towards a more sedentary life and a significant population growth [73].

Discussion. According to the anthropobiotic concept, the megafauna degradation, which began in the final stage of the Paleolithic period, was stimulated by hyper-consumption of the Upper Paleolithic population that specialized in mass procurement of the largest megafauna representatives $[3-5,69,75-77$ et al.]. We have justified this notion with regard to the studied area and have proposed a chronology for this process [33].

Advocates of the climatic concept [62, 78-80] primarily link the extinction of key mammoth fauna species (mammoths, rhinoceros, bison) to climate changes on the turn of the PleistoceneHolocene periods, which triggered reconstruction of the vegetation cover unacceptable for the megafauna [63]. However, the reconstructed appearance of the vegetation cover of the south of the West Siberian Plain demonstrates that there was no drastic change of landscapes due to the Holocene warming in the studied area. The chronology of the mammoth fauna transformation into contemporary faunal complexes that we traced is well in compliance with the model reconstruction of the vegetation cover.

Finally, a serious argument in favour of man's determinant role in the megafauna elimination in the studied area consists in the nature of natural resources exploitation by the Paleolithic population of the West Siberian Plain. Tribes which migrated from the European plains retained in the new areas the achieved level of economic development. The archaeological data $[50,81]$ testify to the spread of 
active hunting, including driven hunt. Although the Paleolithic period of the West Siberian Plain has so far been little studied the so-called "mammoth cemeteries" have already been detected, of which Volchiya Griva and Gari are the largest. These mass accumulations of bones are in principle similar to European cemeteries, for which anthropogenic genesis is widely acknowledged as the result of systematic driven hunt.

According to the palynological data [29, 55 et al.], consistent afforestation of the West-Siberian Plain started in the north of today's boreal area already in the Boreal period and unfolded here much faster than in the south. Moreover, in the north of the West-Siberian Plain successional development of arboreal vegetation, which manifested itself in the change of explerent species to late-successional (climax) species, went more actively, despite the fact that the optimum zone of tree species with a competitive strategy is located in the south. Apparently, these processes reflected the complete fragmentation of the mammoth fauna that started here. Graduate elimination of the most powerful environment-transforming species from eco-systems (or a stable decrease in their population size) caused worsening of the environment unbearable for animals of open and semi-open habitats that died out or migrated to the south [82]. However, still considerable size of megafauna populations in the south of today's boreal area of the West Siberian Plain even in the Atlantic period is indirectly confirmed by the wide spread of large meadowsteppe areas as well as by the abundance of trees with the reactive strategy (the birch and the pine). With further fall in the megafauna size and subsequent afforestation growth, migration paths of gregarious phytophagous species were blocked, their populations got fragmented and were decreasing, pushed away to isolated, least favourable areas. This weakened their ability to withstand weather changes, epizootic diseases, predators and hunters $[53,54]$.

Within the boundaries of the studied area these processes, excluding the mammoth, were obviously occurring in the Atlantic and the first half of the Sub-boreal periods. However, although in the first half of the Holocene the disappearance of the mammoth most certainly contributed to the considerable fall in the mosaic character of the vegetation cover, the initial forest-meadow-steppe structure of the vegetation cover was still being maintained thanks to the activities of the remaining large phytophagous species [82, 83].

Consequently, semi-nomadic and nomadic hunting for the largest megafauna representatives was a predominant type of exploitation of natural resources in the studied area in the Paleolithic,
Mesolithic and Neolithic periods; it also laid the foundations for the anthropogenic transformation of the vegetation cover. Key species of the grazing eco-systems were gradually hunted down, as a result they were replaced by the detritus ones across vast areas, and the forest belt was formed throughout the whole first half of the Holocene. In the Eneolithic era the depletion of gregarious phytophagous populations led to the maximum afforestation of the area and the definitive degradation of the Pleistocene forest-meadow-steppe hyperzone as well as to the crisis of the hunting sector, with the latter to a large extent replaced by sedentary fishing [83].

\section{Reproducing economy epoch}

Bronze Age (Fig. 3)

Model reconstruction of the vegetation cover. The Bronze Age coincides with the second half of the Sub-boreal period (4000-2500 B.C.). The vegetation cover of that time was reconstructed on the basis of the palynological spectra of 24 sequences (see Table 1). Judging by the information they provide, forest degradation began from the middle of the Sub-boreal period in the south of the West Siberian Plain. In the forests in the area of today's southern taiga the remaining meadow-steppe areas expanded. Dark-coniferous and pine forest stands were to a large extent replaced by birch forests. In today's forest-steppe and subtaiga areas the amount of forest has significantly gone down, especially in the Tobol river region. The share of the birch tree has risen sharply whereas the share of the pine has decreased along with dark-coniferous and broad-leafed species.

On the turn of the Subboreal and the Subatlantic periods, the amount of forests of the area currently occupied by the subtaiga and the foreststeppe was regenerated. However, the share of dark-coniferous and broad-leaved trees here was already significantly smaller than in the Eneolithic era. Open spaces were rapidly overgrown with arboreal vegetation. The pine played a significant role in this process, besides the birch tree. In the herbaceous communities the share of meadow species went up. At that time intraforest meadowsteppe communities apparently disappeared on the territory presently occupied by the southern taiga; in a number of cases for the first time in the whole of the Holocene, forests developed a closed canopy. Allochthonic paludification of dry lands was sharply intensified [31].

The spectra of peat accumulations of today's middle taiga, especially in the interfluvial area [29], do not reflect such changes. Throughout the whole of the Bronze Age dark-coniferous taiga was consistently present here, possibly with an insignificant share of broad-leaved species. 


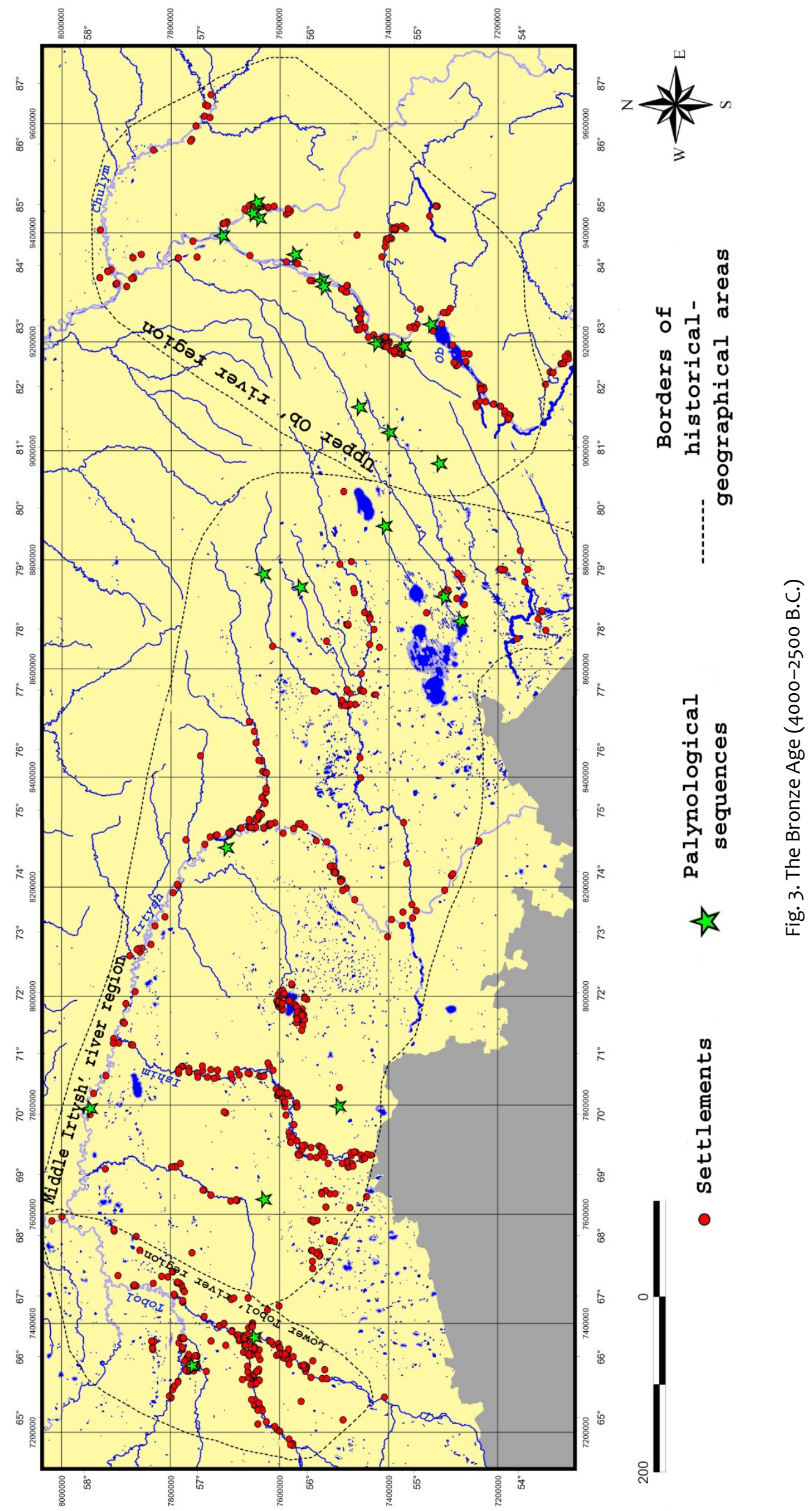


Peculiarities of human settlement and paleoeconomy. With the advent of the Bronze Age migration processes in the south of the West Siberian Plain sharply intensified $[84,85]$. This led to the formation of a raft of archaeological cultures in this area which were part of the Samusk-Seiminsk circle known to have southern roots: Tashkovo, Imbiryi, Odinovo. Loginovo, Igrekovo, Stepanovo, Krokhalevo, Sumusk, Krotovo. Reproducing economy was spreading with the representatives of these cultures in the south of the West Siberian Plain. Under the pressure of more numerous and better developed migrants, the local population was either moving to the north or rapidly assimilating [85]. These processes certainly contributed to the intermittent population growth.

The second period of the developed Bronze Age is linked to a new unprecedentedly powerful migration current of the Andronovo culturalhistorical community representatives. The latter was being formed starting from 3700 B.C. in the areas of the Southern Urals and the Upper Irtysh river region. The settling of the Andronovo culture in the forest-steppe area led to the appearance of the Alakul and Fyodorovo cultures in this area which later on were transformed into the Barkhatovo and Irmensk cultures. On the turn of 3300-3200 B.C. representatives of the Andronovo culture started moving to the north, to the areas presently occupied by the subtaiga and the southern taiga. This resulted in the formation of a huge community uniting hybrid Andronovo-like cultures: Tcherkascul, Pakhomovo, Suzgun, and Elovo. Throughout the whole time of their existence, the Andronovo-like cultures were continuously expanding their area; their population size was also on the rise (Fig. 4). Populations representing cultures within the Andronovo community are characterized by the developed sedentary cattle economy with predominance of cattle in the herd. Farming played a significant role [86-89 et al.]. It is assumed that the fire was in wide use to clean up agricultural lands from forests and increase pasture productivity $[90,91]$.

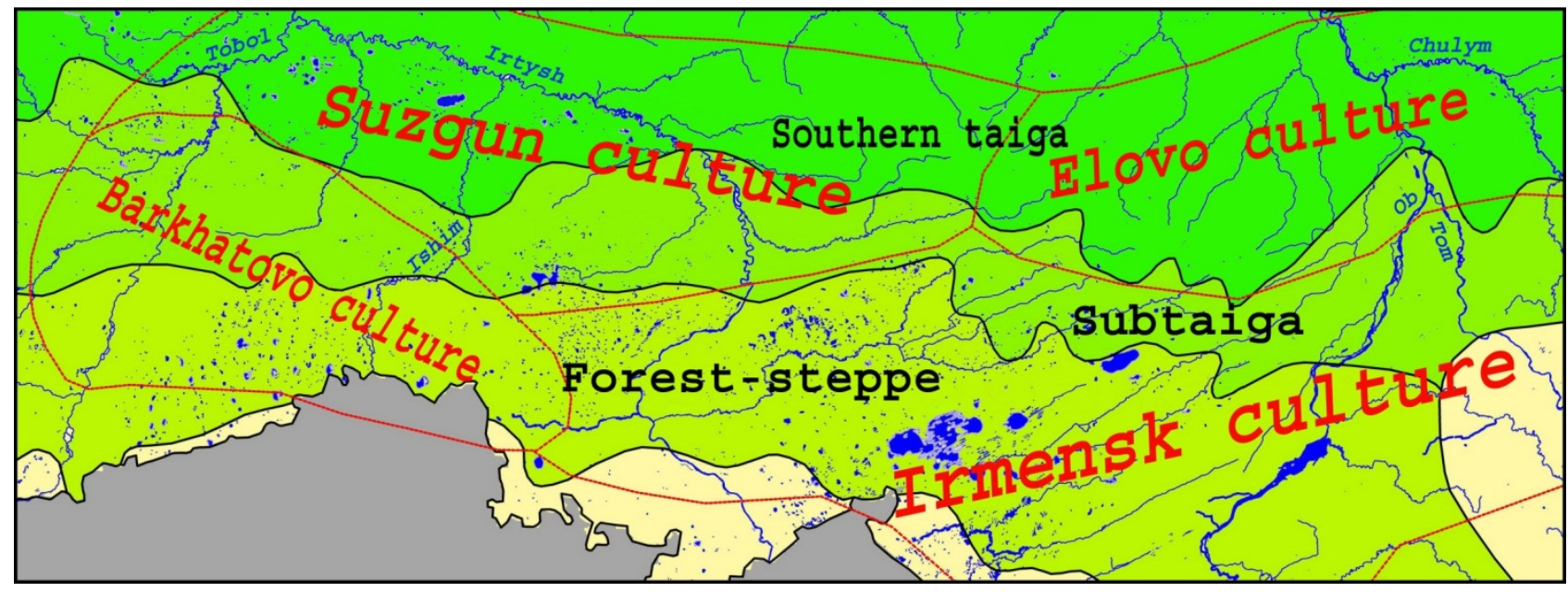

Fig. 4. Main late Bronze Age archaeological cultures of the south of the West Siberian Plain

Starting from 2800 B.C. Bronze Age civilizations started declining in the West Siberia, which marked the transition to the Early Iron Age. First, the number of stationary settlements dwindled and they almost completely disappeared later on. There was a sharp decrease in the population size; the existing economic and cultural types were degrading. We believe $[82,83]$ that these processes testify to the ecological crisis that broke out in the context of overcrowding and depletion of grasslands, against the backdrop of climate warming and climate dryup [22]. It marked the end of the Bronze Age.

Disintegration of Bronze Age stock-raising and farming cultures went hand in hand with the return movement of local tribes to the studied area, from which they were previously forced out to the north by the Andronovo-culture representatives. They assimilated the remaining stock-raising population, which resulted in the formation of the Zavialovo, Molchanovo, Krasnoozersk, and Gamaiunsk cultures. All cultures of the transition period were characterized by the prevalence of appropriating sectors (hunting and fishing). The number and size of settlements shrank, settling was more sparse [92-94].

Discussion. The reconstructed vegetation dynamics as well as peculiarities of exploitation of natural resources by the Bronze Age population led us to the following conclusions.

The significant increase in the sedentary population size and presumed routine use of fire in the economic cycle must have increased the fire hazard manifold in the populated areas, compared with its natural backdrop. The increase in the population 
size would have inevitably led to the increase in the number of ignition sources, while its relative sedentariness and the use of fire in the economy must have made fires more frequent [95]. Obviously, fires accompanied the population throughout the whole of the Bronze Age; they particularly intensified in its late stage.

It is likely that it was exactly this factor that contributed both to the significant expansion of non-forest lands and replacement of darkconiferous and broad-leaved forest stands with birch-tree forests and, most likely, aspen forests. The following became the factors of anthropogenic transformation - less large-scale but important for regeneration of some tree species: forest grazing of cattle, regular elimination of tree undergrowth in the process of livestock browsing procurement for the winter period (in either case broadleaved trees and the fir were particularly badly affected), forest clearing (predominantly, the pine) to build log structures and for bronze-casting metallurgy. Transformational processes largely manifested themselves in river valleys, both large and small, because these did not only represent wellestablished migration paths, but also attraction zones for reproducing economy sectors [87, 96]. Here regular fires of low intensity must have been common (ground fires). In the interfluvial area these processes were less manifested, fires must have occurred less frequently, but these must have been mostly crown fires. Vegetation transformation was particularly intense within the zones of economic activity of settlements [82-83]. Therefore, in the Bronze Age a new factor for meadowsteppe community maintenance in the potential forest area appeared in the regional-scope - the pyrogenic one. It is important to note that abrupt deforestation of the vegetation cover in the studied area as well as vegetation cover transformation into steppe areas in the Bronze Age occurred despite the climatic background (relative cooling and increased level of precipitation) [22].

As a result of the ecological crisis at the end of the Bronze Age, vast spaces fell into neglect, being little exploited by the predominantly fishinghunting population that arrived from the north. In the absence of gregarious hoofed mammals - natural stabilizers of meadow-steppe communities and stock-raising and fires (artificial stabilizers) the amount of forests was rapidly growing in the regions at present occupied by the forest-steppe. To the north, for the first time in the whole of the Holocene closed forests were being formed. This is frequently interpreted as the result of climatic cooling and climate moistening, the so-called "offensive" led by the forest zone on the steppe zone
[97], while the climate, on the contrary, was becoming warmer and more dry with the transition to the Early Iron Age [22].

Early Iron Age and the Middle Ages (Fig. 5)

Model reconstruction of the vegetation cover. The abovementioned epochs coincide with the Subatlantic-I (2500-2000 B.C.) period - the first half of the Subatlantic-III period (1000-500 B.C.). The vegetation cover of this time was reconstructed on the basis of the palynological spectra of 27 sequences (see Table 1). The spectra reflect peculiarities of the vegetation cover development common for both the Early Iron Age and the Middle Ages. Starting from the transition period following the Bronze Age, closed forests were being formed in the area at the moment occupied by the southern taiga and the majority of the subtaiga regions. The share of the birch tree in these forests was considerably going down, whereas the share of dark-coniferous and broad-leaved species as well as that of the pine was on the rise. Throughout most of the Early Iron Age and the Middle Ages, the appearance of the vegetation cover was determined by pine-birch-dark-coniferous forests with a share of broad-leaved trees (the linden, the elm, less frequently - the oak) and the larch-tree. However, the spectra allow concluding that throughout the Early Iron Age and the Middle Ages there were several relatively short periods of forest degradation when birch-tree forests were largely replacing dark-coniferous and broad-leaved forest stands: $\sim 2300-2000$ B.C., $\sim 1000$ B.C.. and, apparently, 500-600 B.C. Starting from the late Middle Ages (around 500 B.C.) the share of dark-coniferous and broad-leaved tree species in forests was consistently going down; the subtaiga forests were becoming more intermittent.

The vegetation of the territory presently occupied by the forest-steppe was developing in a slightly different way. The pine and the birch tree were colonizing this area in large numbers with the beginning of the Early Iron Age; the meadowsteppe areas got overgrown by forests. The forest areas saw increasing presence of dark-coniferous species (the spruce, the cedar, less frequently - the fir), possibly - broad-leaved trees (the linden and the elm). In the herbaceous communities the share of meadow plants was increasing, while the share of steppe plants was going down.

Throughout the most part of the Early Iron Age and the Middle Ages the vegetation cover was dominated by intermittent forests or heavily wooded forest-steppes. The forests were dominated by the birch tree and the pine, the participation of dark-coniferous species was visible; the participation of broad-leaved trees was less frequent. 


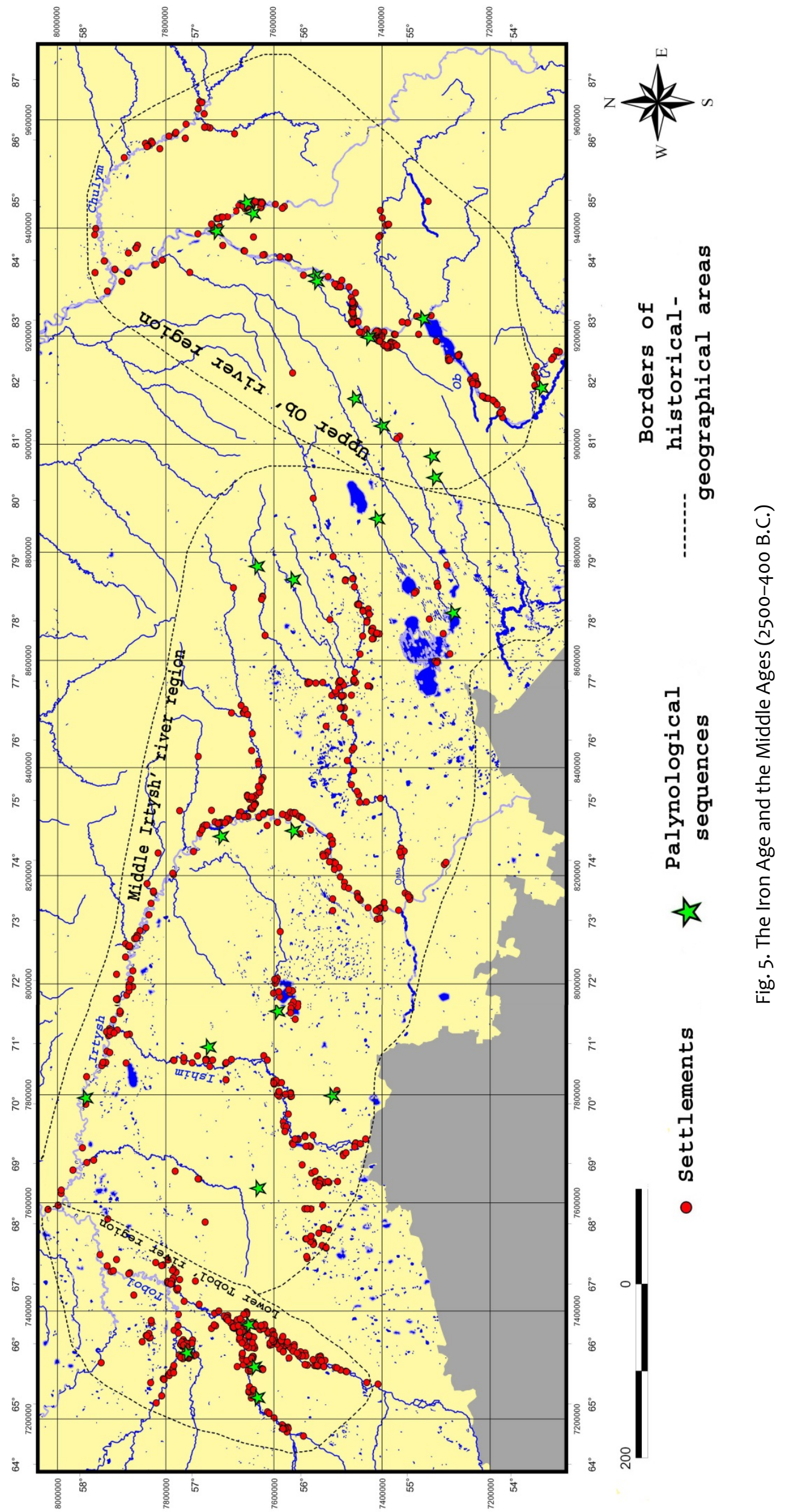


In contrast to the more northern areas, the share of dark-coniferous and broad-leaved tree species was consistently declining throughout the whole period. Just as it was for the more northern regions, in the period of $\sim 2300-2000$ B.C., $\sim 1000$ B.C. as well as at the beginning of the late Middle Ages the amount of forests in the area was in considerable decline, the meadow areas with prevalence of gramineous species were expanding. In forest stands the share of the birch-tree was increasing, the participation of the pine and the darkconiferous tree species was going down. Apparently, birch-tree forest outliers were spreading, possibly with a small share of dark-coniferous trees.

Peculiarities of human settling and the paleoeconomy. Approximately after 2500 B.C. the studied area was populated by representatives of the Baitovo, the Bogochanovo and the Kulaisk cultures, classified as being little developed from the economic point of view. Hunting and fishing were essential in the paleoeconomy of the population; stock-raising occupied the subordinate position. The settling was characterized by intermittency; settlements were insignificant in size [98-100]. However $\sim 2300-2000$ B.C. under the influence of new migrations from the south two highly developed and very large archaeological cultures were formed in the areas currently occupied by the forest-steppe, namely - the Sargat and the Bolsherechensk cultures [101-104]. At that time fisherman and hunters - representatives of the Kuliask culture - continued to inhabit the area of today's southern taiga and the subtaiga. The paleoeconomy of the population of the Sargat and the Bolsherechensk cultures was based on the developed stock-raising - farming reproducing economy. Significantly increased population dispersion and mobility began to constitute the main difference between the reproducing economy of that epoch and that of the Bronze Age. Obviously, not only did this allow the population to maintain the same grazing pressure but also to considerably increase the cattle herd size. However already in $\sim 1800$ 1600 B.C. the Sargat and the Bolsherechensk cultures were destroyed in the process of the great transmigration of peoples [101, 102, 104]. As a result, the West Siberian forest-steppe got deserted for a long time; it was gradually populated by representatives of the Kulai culture, moving in from the north. Overall, representatives of the Kulai culture sustained their economy-cultural type. Despite the fact that by the end of the Early Iron Age the share of stock-raising did increase, settling remained intermittent, the share of appropriating sectors remained high [98].

In the early Middle Ages (1500-1000 B.C.) the huge Kulai community disintegrated. The Kulai descendants formed Potchevash, Relka, Upper $\mathrm{Ob}$ and Molchanovo cultures. Stock-raising was the core of their economy; hunting and fishery played a significant role. The Kulai people descendants inherited the intermittent settlement network [96, $105,106]$. In the period of $1100-900$ B.C. the population of various Turkic-speaking ethnicities were actively penetrating today's forest-steppe and subtaiga regions of the West Siberia [107]. Active assimilation processes in this area resulted in the formation of Srotkino, Basandaisk, Ust-Ishimsk, Yudino and Bakalsk cultures. Population size and density increased; the share of reproducing sectors increased in the economy [105, 107-109]. However already in $\sim 800$ B.C. these cultures were destroyed in the process of the Mongol conquest. The studied area was made part of the Siberian Khanate after a lengthy period of instability. From this time onward semi-nomadic stock-raising occupied the leading position in the population's economy. This was determined not so much by the ecological priorities as by the continuous war threat. The period of stable development of the Siberian Khanate itself comprised some 200 years: $\sim 600-500$ B.C. From the turn of the $\sim 500$ B.C. a new period of prolonged internecine wars began, which ended in a definitive disintegration of the Siberian Khanate and the inclusion of the studied area into the orbit of socio-economic development of the Russian Empire [105, 110, 111].

Discussion. As it follows from the analysis, archaeological cultures both of the transition period and the first centuries of the Early Iron Age are characterized by intermittent population, relatively low economic development. From the outset of the Early Iron Age stock-raising population completely abandoned today's southern taiga and partly subtaiga regions. Intraforest meadows - previously maintained by the man disappeared; in a number of cases this was followed by irreversible swampformation (swamping) [31]. Dark-coniferous forests were regenerating in the areas not covered by swamps. These forests, predominantly populated by forest animal hunters and fishermen, existed unaffected by any serious changes (obviously, with the exception of local degradation changes around the settlements) throughout the whole of the Early Iron Age and for most of the Middle Ages.

On the whole, prolonged periods within the Early Iron Age and the Middle Ages coincided with the military and post-military recessions, a significant part of lands was taken out of the economic turnover. In the forest-steppe demographic and economic recessions led to the fall of anthropogenic pressure and overgrowth of former pastures with the birch-tree and the aspen as well as pine forests. In the forests remaining from the 
Bronze Age, opportunities for regenerative change of forest stands were arising. However part of the stock-raising population remained, gradually forming new cultures. Anthropogenic impacts characteristic of the stock-raising population also continued to act. Inevitable ground fires were no longer causing mass deforestation but contributed to the stable existence of forest communities with prevalence of birch-tree forests in the interfluvial areas and pine forests on the terraces. These fires also contributed to the stable existence of allegedly small pasture communities that the population needed for grazing. Species which were less able to withstand such anthropogenic pressure, namely dark-coniferous and broad-leaved species, were gradually disappearing from the forest stand composition [82-83].

Forest vegetation degradation periods, which we reconstructed, chronologically coincide with the relatively short (200-300 years) periods of population growth, stabilization and increase in the effectiveness of the reproducing economy. We believe that changes in the natural environment resulted from the changes in the socio-economic environment; the former also reflected increased anthropogenic pressure on the vegetation cover. The most drastic anthropogenic degradation of natural communities in the area currently occupied by the forest-steppe and partly the subtaiga, apparently, was occurring at the prime time of the Sargat and Bolsherechensk cultures. Ongoing climate warming may have contributed to this process [22]. In around 2000 B.C. landscapes experienced anthropogenic degradation comparable with the late Bronze Age degradation. Grazing and ground fires within the significantly expanded economic zones of settlements brought about [112] a sharp increase in the surface of the meadow-steppe areas. Once again shrinking forest areas were starting to be dominated by the birch-tree, most capable to withstand the anthropogenic pressure, and apparently the aspen (no pollen remains in the spectra). Vegetation typical of the birch-tree forest-steppe was being formed, in which small birch-tree forest outliers were with meadows exhibiting various degrees of steppification. In areas with relatively low size of grazing herds, forest grazing led to the formation of bleached park-type forests. Previously little exploited areas deep in the interfluvial regions were being included into the economic turnover. According to the palynological data, it is presumed that the fire frequency was significantly increasing in the interfluvial areas [82, 83].

In the Middle Ages anthropogenic transformation of the forest-steppe vegetation was unfolding in a similar way but less intensively in approximately 1000 B.C. and apparently in 600 B.C. Moreover, during these periods local population was partly forced out of the area into forest areas currently occupied by the southern taiga and the subtaiga by migrants from the south. This was increasing the population size in this area, which in turn was increasing the fire frequency. The pyrogenic impact as well as the continuing swamp formation contributed to the disappearance of dark-coniferous and broad-leaved tree species from the composition of the boreal forests [83].

Modern era. Peasant colonization (XVIIXIX вв.) (Fig. 6)

Model reconstruction of the vegetation cover. Changes in the vegetation cover in the XVIIXIX centuries were reconstructed on the basis of the pollen spectra of 27 sequences (see Table 1). Data from the travel notes and reports were used [113]. For the final stretch of the period (end of the XIX century) professional descriptions of the vegetation were used [114-118 et al.] along with the cartographic materials [119].

Generalization of the results of the spectra analysis and historical data revealed the peculiarities of the vegetation cover development in the studied area at the time of peasant colonization. In the XVI-XVIII centuries boreal forests with a relatively high share of dark-coniferous and broadleaved tree species were wide-spread in an area of the southern taiga, mostly along the right Irtysh river bank across the Northern

Baraba to the $\mathrm{Ob}$ river region near Tomsk. However, by the end of the XIX century the participation of key tree species abruptly went down these were replaced with the birch-tree.

These processes apparently were manifested much earlier in the seriously swamped southerntaiga area of the Tobolsk district along the left river bank of the Irtysh river [120].

Throughout the XVI-XVIII centuries the major part of the subtaiga - on the territory of the Ishima and especially the Baraba Plains had forests with various degree of intermittence and with different participation of dark-coniferous and broad-leaved trees (however, their share was lower than in the southern-taiga areas). In the subtaiga districts of the Lower Tobol river region these were already replaced with large pine and birch-tree forest areas. Starting mid-XIX century up until the beginning of the XX century almost all tree species disappeared from the most part of the subtaiga, apart from small-leaved trees; open space surfaces sharply increased. Small-leaved forests started to dominate on the right river bank of the Tara river, in the Northern Baraba and the Ob-Tomsk interfluvial area only at the end of the XIX century. Up until the XVIII century today's forest-steppe (in the Baraba case apparently up until the beginning of the XIX century) from the physiognomy point of view resembled bleached birch-tree-aspen forests mixed with large meadow-steppe areas. 


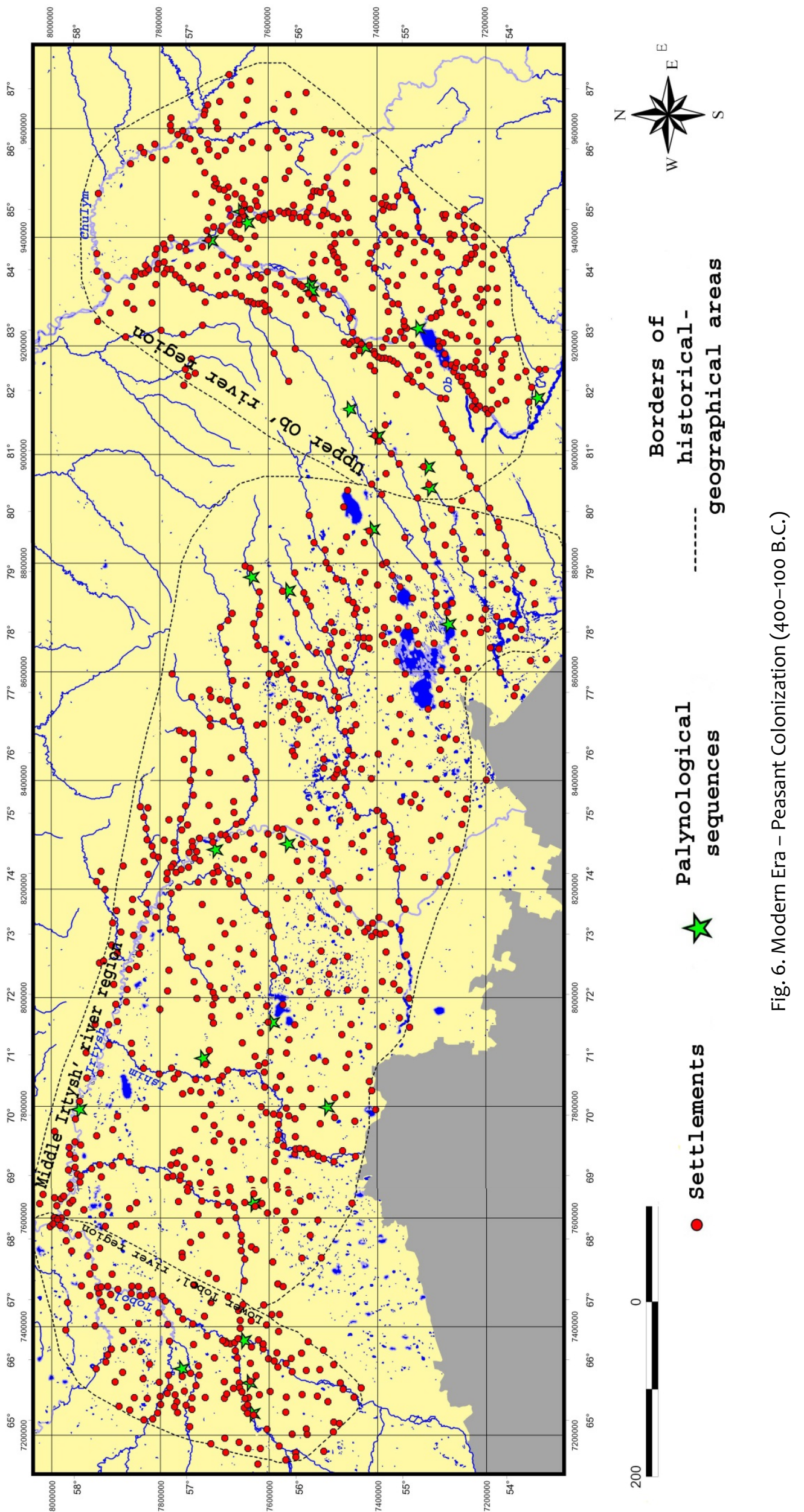


Dark-coniferous species - the pine and the cedar - continued to exist in the forest stands. Pine forests consistently existed on the terraces with light soils. The southern border of the forest-steppe lay beyond the boundaries of the West Siberian Plain. Starting from the XIX century, the amount of forests was decreasing and pine and darkconiferous forests were disappearing here allegedly much faster than in the subtaiga [120].

Peculiarities of human settling and economy. In the XVII century agricultural exploration of the West Siberia unfolded along the large rivers from the west to the east in forest regions and touched the forest-steppe only partly. Settling of the territory in the XVII century was determined not by the agricultural potential of the area as it was in European part of Russia, but by the complicated military and political situation in the steppe and the forest-steppe. Firm exploration of the forest-steppe areas began only in the $1840 \mathrm{~s}-1850 \mathrm{~s}$. The most large-scale migrations of peasants from the European part of the country to the West Siberia were occurring in the second half of the XIX century [121-123].

Up until the end of the XIX century there was one domineering complex extensive farming system in the West Siberia, namely - the laylandfallow one. It consisted in combining within one farming household the permanent three-field system in the fertilized areas nearest to the settlements (that is the tithe farm field) and the periodic leas on the farther unfertilized areas ("the very special farm land"). The overall surface of the numerous farther plough lands ("squatter's lands") exceeded several-fold the surface of annual seeding and fallow. The squatter's lands had dozens of kilometers between them because vast land areas necessary for the extensive system did not allow setting them up at a smaller distance. The squatter's lands were used both for plowing and hay-harvesting. It is believed that the permanent network of seasonal settlements on the squatters' lands was not only a mechanism for colonizing the lands but was in fact a stable settling system [124-125].

From the XVIII century stock-raising became one of the crucial sectors of the peasant economy. It was particularly well developed in the foreststeppe areas [126]. Forests constituted a significant part of grazing lands and especially haylands [127]. Scorching was the most common method for improving pastures and fields ("Siberian burn") [128]. Burns covered enormous surfaces and lasted several days [129].

Development of trade-market relations took the exploitation of the Siberian forest resources to a new level. First and foremost, timber was used for construction work and heating. Across the whole of the region's forest belt peasant wood processing was developed; it was accompanied by shelterwood felling and selective cutting $[115,130]$. In the $1850 \mathrm{~s}$ the following production made from brasswood splint was brought to the Irbitsk fair alone from the Tobolsk, Tumen and Tarsk districts: up to 200,000 items of different burlaps, up to 50,000 "different boxes, whole carts of ropes of all kinds of thickness and length" [131].

Discussion. The following were the main forms of anthropogenic transformation of the forest cover in the south of the West Siberian Plain during the period of peasant colonization:

1. Fires which reached unprecedented scope in the context of the settling of peasants $[118,129$, 132-134]. Uninterrupted ground fires (often transforming into the crown fires) were the main reason for the fall in the amount of forests in the foreststeppe and the subtaiga along with the extermination of dark-coniferous and broad-leaved tree species with low resistance to this type if impact. In the southern taiga crown fires had slightly lower frequency (determined by lower population density), but much higher intensity respectively and resulted in considerable substitution of boreal forests with birch-tree forests [120].

2. Forest cutting. Forest extermination for agricultural needs also stimulated progressing deforestation of the area, first and foremost in the subtaiga and forest-steppe districts [118]. As a result of selective cuttings, populations of the most rare and valuable from the trade point of view dark-coniferous and broad-leaved trees as well as the those of the larch tree were destroyed [115, $118,132]$.

3. As a result of forest grazing and hay harvesting, forests were deprived of the undergrowth of dark-coniferous and broad-leaved trees. This issue was particularly acute in the isolated forest areas in the forest-steppe and the subtaiga, where regeneration of dark-coniferous and broad-leaved tree species was made almost impossible due to the great remoteness of seed-producing trees of these species [120].

Model reconstruction of the vegetation cover dynamics in the south of the West Siberian Plain from the late Pleistocene up until the end of the XIX century.

The vegetation cover dynamics of the studied area from the late Pleistocene up until the end of the XIX century may be vividly demonstrated in a series of principal map-charts that we developed [83].

The Pleistocene - beginning of the Holocene (the Pre-boreal period) (the Paleolithic period the Mesolithic period) (Fig. 7). 

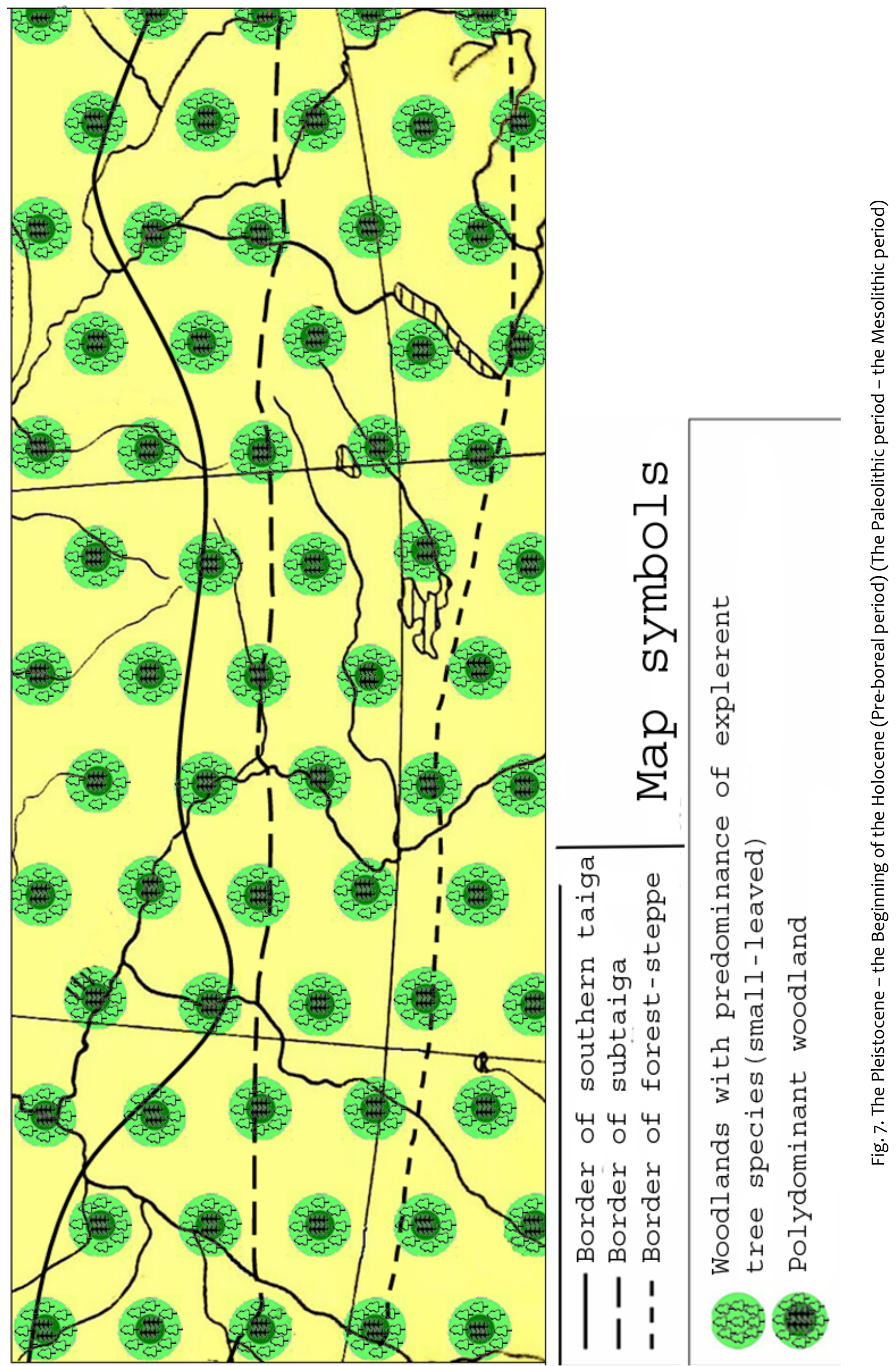
Throughout the Pleistocene forest-meadowsteppe vegetation was formed, in which key species of pasture ecosystems (gregarious hoofed mammals and proboscideans) support vast open spaces. Detritus ecosystems represent forest areas, where late-successional tree species (darkconiferous and broad-leaved) constitute the nucleus. The periphery is the zone of fractional forest grazing of gregarious phytophagous species which suppress the development of the undergrowth of key tree species and determine permanent predominance of explerent tree species (small-leaved). No differences are traced between the vegetation cover of the areas of today's geographical zones. The vegetation cover was in general stable despite significant fluctuations of the climate in the Pleistocene.

First half of the Subboreal period (the Eneolithic period) (Fig. 8).

Pleistocene forest areas went through considerable expansion due to minimization of environment-forming activities of the key species of pasture ecosystems and the substitution of pasture ecosystems with the detritus ones. Explerent tree species occupied former open spaces; key tree species increased their participation as they underwent regenerative succession. No differences are traced between the vegetation cover of areas of today's geographical zones.

Second half of the Subboreal period (the Bronze Age) (Fig. 9).

For the first time asynchronous vegetation development is traced in the studied area. As a result of fires induced by the Bronze age population and grazing in today's forest-steppe area, forest areas went down considerably, with minimal participation of key tree species. In the context of lower intensity of the anthropogenic activities (downgrading of farming and stock-raising effectiveness further to the north), forest areas in the sub-zones of today's subtaiga and the southern taiga did not decrease, but the participation of the key tree species in them sharply declined. Grazing, hay-harvesting and fires supported large open space areas among forests.

Middle of the Subatlantic period (the end of the Early Iron Age, major part of the Middle Ages) (Fig. 10).

Asynchronous vegetation development continued in the north and in the south of the studied area. Disintegration of stock-raising-farming cultures in the area of today's southern taiga lead to a sharp fall in the anthropogenic pressure on the vegetation cover in this area. In the absence of the key species of pasture ecosystems and in the context of fire frequency reduction, this potential forest area was overgrown with the forest. In the forests the share of dark-coniferous and broad-leaved tree species increased. However, intensive swamp-formation that started in the area hindered the spread of the dark-coniferous taiga.

In the area of today's subtaiga and forest-steppe anthropogenic pressure on the vegetation also went down due to frequent wars and considerable efflux of population; significant surfaces of meadowsteppe areas were overgrown with forest. However, regular anthropogenic impacts of low intensity lead to gradual disappearance of key tree species out of forest communities and also supported open space areas, required for reproducing economy.

End of the Subatlantic period (Period of peasant colonization) (Fig. 11).

Settling of peasants - representatives of developed reproducing economy - across the whole of the studied area lead to large-scale degradation of forest vegetation. The degradation process was most intensive in the area of today's forest-steppe and the subtaiga; it was manifested through the sharp reduction in the amount of forests, overall northward shift of the southern border of the forest spread, definitive dropout of key tree species out of the composition of forest communities. Due to universal swamp spread, today's southern taiga did not become part of the overall farming exploitation zone. However, being a border region, it experienced the impact of regular forest fires, which sharply decreased the participation of darkconiferous and broad-leaved tree species in the forests.

\section{Conclusions}

1. Verbal reconstruction includes the following statements. Pre-anthropogenic vegetation cover of the south of the West Siberian Plain dates back to the late Pleistocene when meadow-steppe communities - major pastures for key species of the mammoth complex - were dominant. They were accompanied by forest outliners from darkconiferous and broad-leaved trees of different species. Temporarily abandoned as the result of overgrazing, pastures were overgrown with smallleaved and light-coniferous trees of different species. The establishment of the anthropogenic factor in the vegetation development is linked to the hunting specialization of the population of the late Pleistocene - early Holocene (for large gregarious phytophagous species - key species of the mammoth complex). Their extermination in the period of 12000-4000 B.C. determined considerable reduction of surfaces occupied by the meadow and steppe communities as well as the expansion of surfaces occupied by forest communities, first and foremost by small-leaved and light-coniferous ones. 

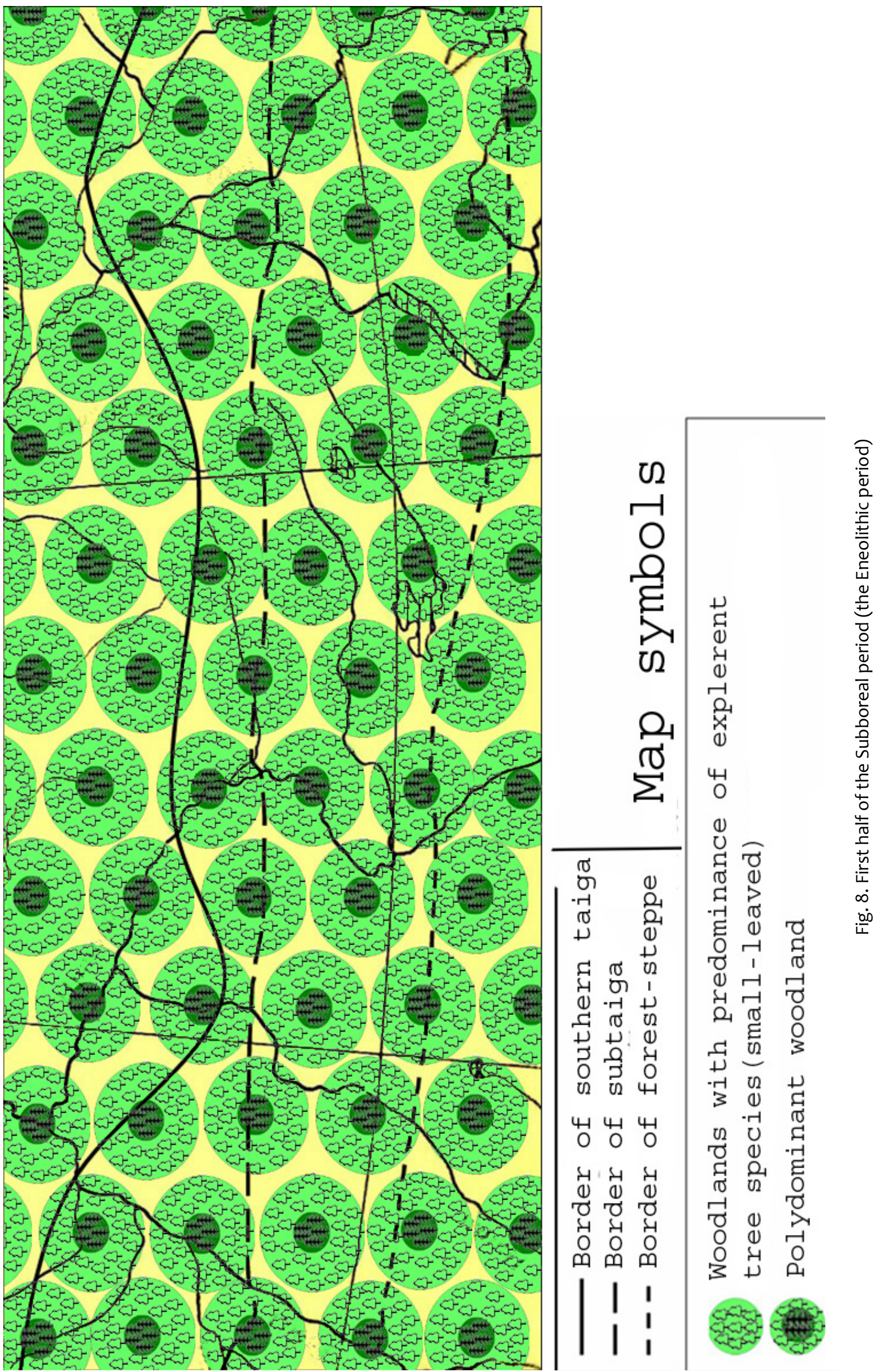


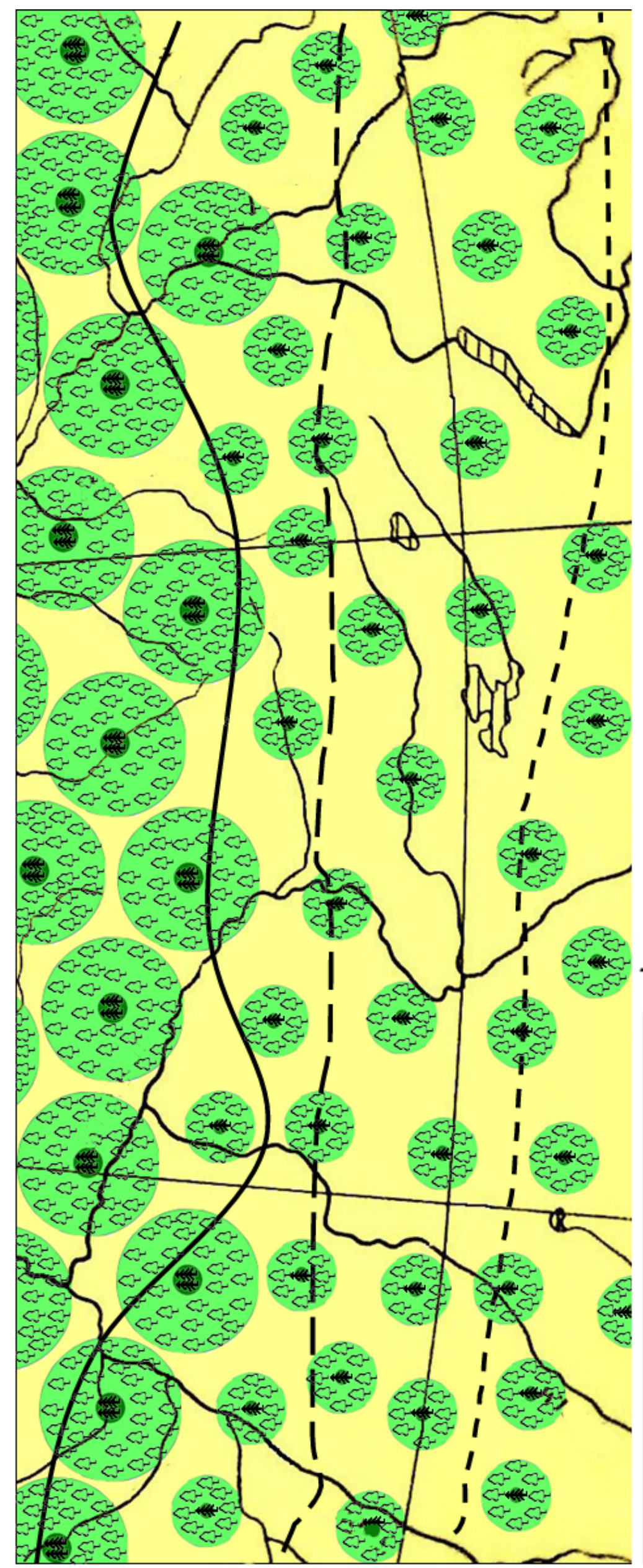

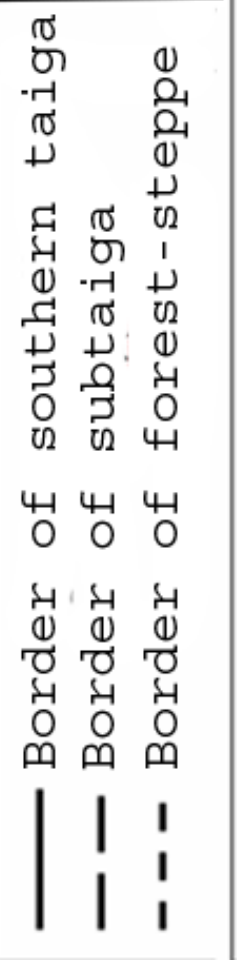

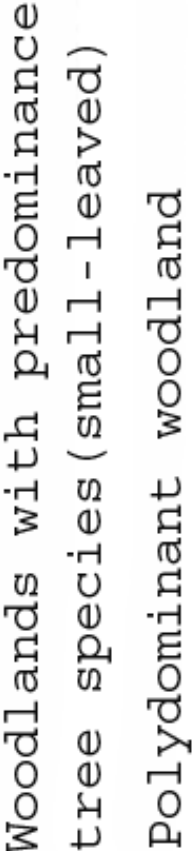

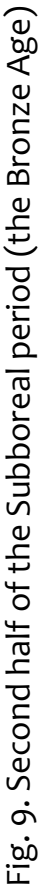




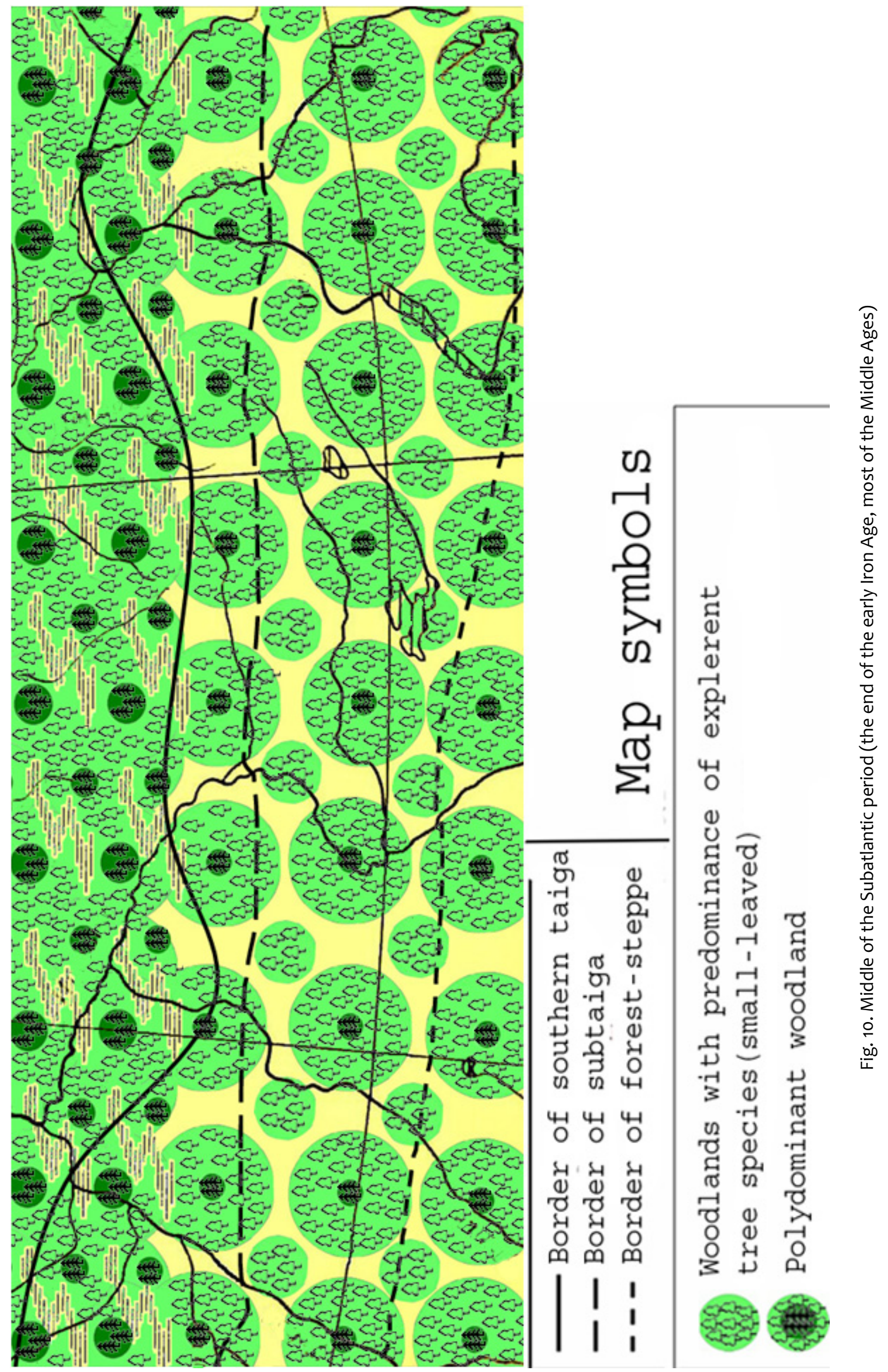




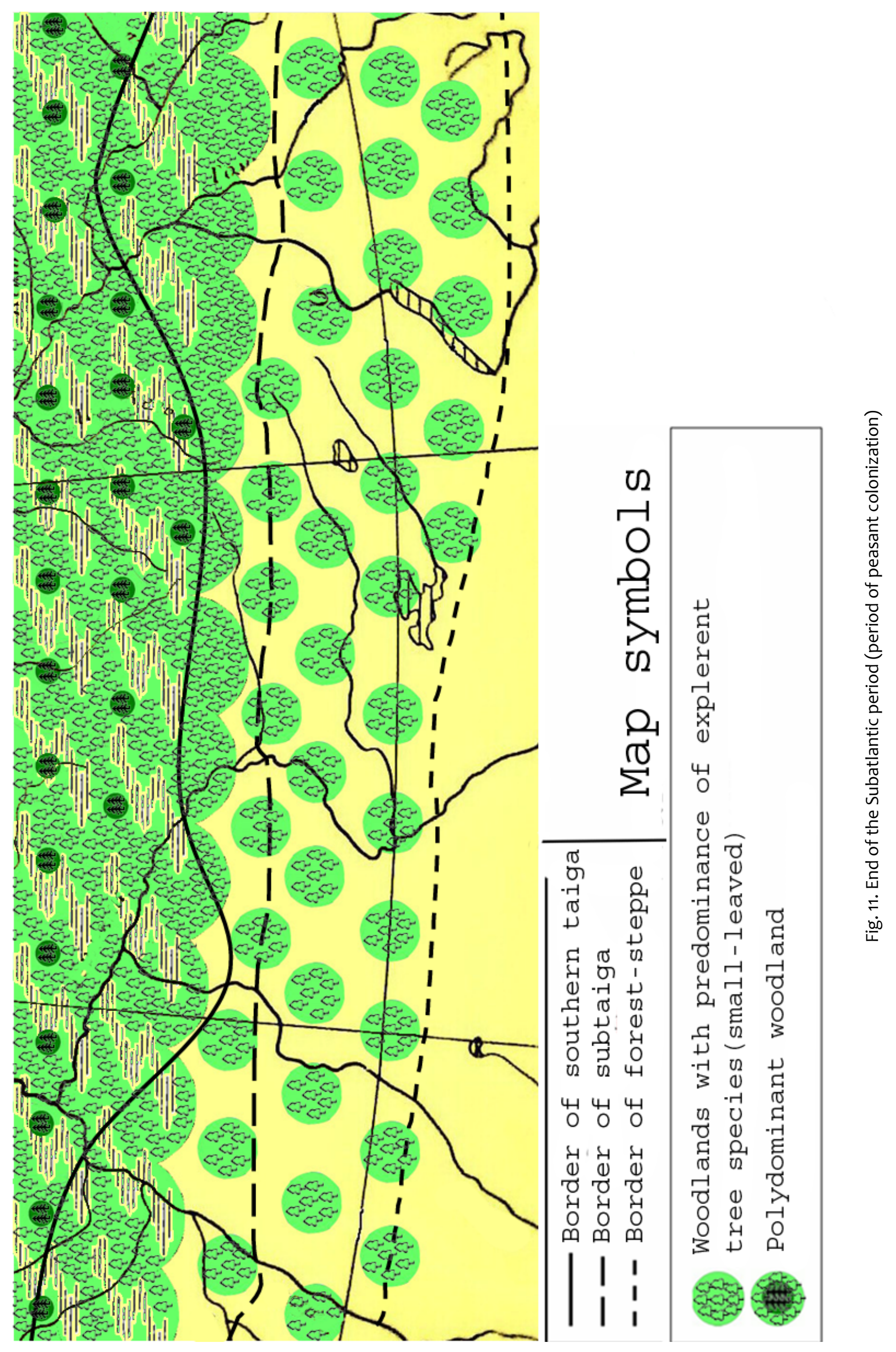


2. Chronological analysis identified the periods of intensification and decline of the anthropogenic transformation of the vegetation cover in the south of the West Siberian Plain. Intensification periods: late Paleolithic period - Neolithic period - intensive development of the reproducing economy; the Bronze Age - first prime of the reproducing economy; peasant colonization of the Siberia in the XVII-XVIII centuries - second prime of the reproducing economy. Periods of decline: the Eneolithic period - decline of the hunting activities due to depletion of resources; Early Iron Age Middle Ages, marked by mass efflux of population and frequent wars.

3. We have identified two major forms of anthropogenic transformation of the vegetation cover of the south of the West Siberia Plain, which had most impact on its composition and structure: a. Specialized hunting for gregarious phytophagous species formed in the context of appropriating economy; b. Man-induced fires, which resulted from the spread of reproducing economy and increase in the population size. The former led to drastic reduction of natural meadow-steppe communities and the formation of the forest belt, the latter led to the deforestation of woodlands and extermination of dark-coniferous and broad-leaved tree species. The following may be classified as additional forms: forest grazing and hay harvesting (contributed to the extermination of dark-coniferous and broad-leaved species), cutting (gained significance only as the forest acquired trade value and contributed to the overall degradation of forest communities).

\section{Conclusion}

The present paper examined the vegetation evolution of the south of the West Siberian Plain from the late Pleistocene up until the end of the XIX century from the standpoint of the anthropobiotic concept of the vegetation cover development. We have demonstrated the dominant role of human activities in this process against the backdrop of climatic fluctuations that accelerated or slowed down processes induced by the economic activities.

Overestimation of the role played by the anthropogenic factor in the development of natural communities in the studied area created an opportunity and a necessity to reconsider today's notions of formation and development of vegetation types, interpreted as the zonal ones.
We have identified dominant and subordinate factors of the formation of the three contemporary zonal units of a large physiographic country: subzones of the southern taiga and subtaiga, foreststeppe zones.

The so-called "native" southern taiga [135, p. 83], that is the zone of closed dark-coniferous forests, was established in the studied area in 2500-2000 B.C. as gregarious phytophagous species - key species of pasture ecosystems - completely ceased their environment-transforming activities. It was also a consequence of disintegration and degradation of the Bronze Age stock-raising economy in this area, which up to this period contained the spread of the continuous forest strip. Nonetheless, it is not quite correct to classify West Siberian southern taiga as the forest zone, taking into consideration the ratio of surfaces occupied by open swamps and woodlands.

Starting from the beginning of the reproducing economy spread in the area, the southern nearborder forest zone strip was continuously experiencing anthropogenic impact; by the mid-XIX century it completely lost its set of key tree species, having turned into a strip with absolute prevalence of the explerent species of small-leaved trees. However, already from the end of the XIX century - first half of the XX century it broke down into a raft of more or less large small-leaved woodlands and its appearance evened out with that of the forest-steppe.

The wide zone of the birch-tree forest-steppe developed as such, having completely lost both all key species of pasture ecosystems (beginning of the Bronze Age) and all the key species of detritus ecosystems (mostly by the beginning of the XIX century), and is maintained exclusively by the man.

It is obvious that further work must consist in creating an even network of spots - places of sample selection for palynological analysis as well as in radiocarbon dating of peat samples which should be as detailed as possible, which will make it possible to more correctly evaluate surface ratios for key land facies and identify features of anthropogenic impacts on the vegetation cover.

The author is aware that a number of statements of the present work are contentious and were formulated as preliminary hypotheses. Some of them may not be confirmed by further research in each of the concerned areas. However, this attempt will allow stimulating the use of interdisciplinary approach while examining large elements of the Earth's vegetation cover.

\section{Cписок литературы}

1. Антипина, Е. Е. Некоторые проблемы изучения истории взаимодействия хозяйственной деятельности человека с природными биоценозами / Е. Е. Антипина, С. П. Маслов // Эволюционная и историческая антропоэкология. - М. : Наука, 1994. - С. 111-120.

2. Калякин, В. Н. Млекопитающие в экосистемах южного Ямала / В. Н. Калякин // Млекопитающие в наземных экосистемах. - М. : Наука, 1985. - С. 67-99. 
3. Пучков, П. В. Некомпенсированные вюрмские вымирания. Сообщение 1. Крупнейшие растительноядные: эври- или стенобионты? / П. В. Пучков // Вестник зоологии. - 1991. - № 5. - С. 45-53.

4. Пучков, П. В. Некомпенсированные вюрмские вымирания. Сообщение 2. Преобразование среды гигантскими фитофагами / П. В. Пучков // Вестник зоологии. - 1992. - № 1. - С. 58-66.

5. Пучков, П. В. Некомпенсированные вюрмские вымирания. Сообщение 3. Перепромысел, «недопромысел» и другие факторы / П. В. Пучков // Вестник зоологии. - 1992. - № 4. - С. 73-80.

6. Shifting mosaics in grazed woodlands driven by the alternation of plant facilitation and competition / H. Olff, F. W. M. Vera, J. Bokdam, E. S. Bakker, J. M. Gleichmann, K. de Maeyer, R. Smit // Plant biol. - 1999. - Vol. 1. P. $1-11$.

7. Смирнова, О. В. Современная зональность Восточной Европы как результат преобразования позднеплейстоценового комплекса ключевых видов / О. В. Смирнова, В. Н. Калякин, С. А. Турубанова, М. В. Бобровский // Мамонт и его окружение: 200 лет изучения. - М. : ГЕОС, 2001. - С. 200-208.

8. Смирнова, О. В. Представление о потенциальном и восстановленном растительном покрове лесного пояса Восточной Европы / О. В. Смирнова, Е. Ю. Бакун, С. А. Турубанова // Лесоведение. - 2006. - № 1. C. 23-33.

9. Горшков, В. Г. Биотический насос атмосферной влаги как движущая сила круговорота воды на суше / В. Г. Горшков, А. М. Макарьева // Hydrology and Earth System Sciences. - 2007. - № 11. - P. 1013-1033.

10. Doughty, C. E. Biophysical feedbacks between the Pleistocene megafauna extinction and climate: The first human-induced global warming? / C. E. Doughty, A. Wolf, C. B. Field // Geophys. Res. Lett. - 2010. - Vol. $37 .-5$ p.

11. Орлова, Л. А. Развитие природных ландшафтов и древних культур Барабы во второй половине голоцена / Л. А. Орлова, Т. П. Левина // Эволюция климата, биоты и среды обитания человека в позднем кайнозое Сибири. - Новосибирск : Изд-во СО РАН, 1991. - С. 72-78.

12. Зыкин, В. С. Изменения природной среды и климата в четвертичном периоде юга Западной Сибири / В. С. Зыкин, В. С. Зыкина, Л. А. Орлова, А. А. Круковер, И. В. Форонова // Проблемы реконструкции климата и природной среды голоцена и плейстоцена Сибири. - Новосибирск : Изд-во ИАЭТ СО РАН, 1998. C. 175-191.

13. Рябогина, Н. Е. Палеоэкологические условия обитания носителей доисторических культур Тюменского Притоболья в голоцене / Н. Е. Рябогина, Т. Г. Семочкина, С. И. Ларин // Экология древних и современных обществ. - Тюмень : Изд-во ИПОС СО РАН, 1999. - С. 61-63.

14. Болиховская, Н. С. Основные этапы развития перигляциальной растительности центра и юга Русской равнины в период существования мамонтовой фауны / Н. С. Болиховская, В. С. Гунова, В. М. Соболев // Мамонт и его окружение: 200 лет изучения. - М. : ГЕОС, 2001. - С. 168-187.

15. Волкова, В. С. Климатическая ритмика голоцена центральной части Западно-Сибирской равнины (палинология, магнетизм) / В. С. Волкова, 3. Н. Гнибиденко, А. А. Горячева // Основные закономерности глобальных и региональных изменений климата и природной среды в позднем кайнозое Сибири. - Новосибирск, 2002. - Вып. 1. - С. 48-57.

16. Троицкий, С. Л. Основные положения миграционно-климатической концепции / С. Л. Троицкий // Проблемы стратиграфии и палеогеографии плейстоцена Сибири. - Новосибирск : Наука, 1982. - С. 7-10.

17. Динесман, Л. Г. Экология растений и животных и количественная биоиндикация палеоклиматов / Л. Г. Динесман // Палеоклиматы позднеледниковья и голоцена. - М. : Наука, 1989. - С. $48-51$.

18. Вальтер, Г. Общая геоботаника / Г. Вальтер. - М. : Мир, 1982. - 261 с.

19. Коновалов, А. А. К определению палеоклиматов по палинологическим данным / А. А. Коновалов, С. Н. Иванов // Экология древних и современных обществ : тез. докл. конф. - Тюмень : Изд-во ИПОС СО РАН, 2003. - Вып. 2. - С. 53-56.

20. Алтухов, Ю. П. Генетические процессы в популяциях / Ю. П. Алтухов. - М. : Наука, 1983. - 179 с.

21. Завадский, К. М. Вид и видообразование / К. М. Завадский. - Л. : Наука, 1968. - 404 с.

22. Монин, А. С. История Земли / А. С. Монин. - Л. : Наука, 1977. - 228 с.

23. Чумичёв, С. А. Климат голоцена по естественно-научным данным и его отражение в исторических хрониках: корни системных противоречий / С. А. Чумичев // Альманах цивилизационных исследований. Новая Парадигма 1 (Хожение в Ойкумену). - 2003. - URL: www.newchrono.ru/frame1/Publ/CLIMATE.htm

24. Восточноевропейские леса: история в голоцене и современность / отв. ред. О. В. Смирнова. - М. : Наука, 2004. - Кн. 1. - 479 с. ; Кн. 2. - 575 с.

25. Смирнова, О. В. Сукцессионный статус старовозрастных темнохвойных лесов Европейской России / О. В. Смирнова, М. В. Бобровский, Л. Г. Ханина, В. Э. Смирнов // Успехи современной биологии. - 2006. T. 126, № 1. - C. 27-49.

26. Смирнова, О. В. Сукцессия и климакс как экосистемный процесс / О. В. Смирнова, Н. А. Торопова // Успехи современной биологии. - 2008. - Т. 128, № 2. - С. 129-144.

27. Мониторинг биологического разнообразия лесов России: методология и методы / отв. ред. А. С. Исаев. М. : Наука, 2008. - 453 с.

28. Х Хотинский, Н. А. Голоцен Северной Евразии / Н. А. Хотинский. - М. : Наука, 1977. - 200 с.

29. Бляхарчук, Т. А. История растительности юго-востока Западной Сибири в голоцене по данным споровопыльцевого и ботанического анализа торфа : дис. ... канд. биол. наук / Т. А. Бляхарчук. - Томск, 1989. $248 \mathrm{c}$. 
30. Орлова, Л. А. Голоцен Барабы. Стратиграфия и радиоуглеродная хронология / Л. А. Орлова. - Новосибирск : Наука, 1990. - 128 с.

31. Болотные системы Западной Сибири и их природоохранное значение / под ред. В. Б. Куваева. - Тула : Гриф и $\mathrm{K}^{\circ}, 2001 .-584$ с.

32. Рябогина, Н. Е. Стратиграфия голоцена южного Зауралья, изменение ландшафтно-климатических условий обитания древнего человека : дис. ... канд. геол.-минерал. наук / Н. Е. Рябогина. - Тюмень, 2004. - 419 с.

33. Харитоненков, М. А. Роль антропогенного фактора в формировании растительного покрова юга ЗападноСибирской равнины в эпоху традиционного природопользования (с позднего палеолита до конца XIX в.) : дис. ... канд. биол. наук / М. А. Харитоненков. - М., 2012. - 308 с.

34. Букреева, Г. Ф. Зональные особенности составов рецентных спорово-пыльцевых спектров долины р. Оби и их взаимосвязь с показателями современного климата / Г. Ф. Букреева, Г. М. Левковская // Проблемы реконструкции климата и природной среды голоцена и плейстоцена Сибири. - Новосибирск, 2000. - Вып. 2. C. $48-56$.

35. Васильев, С. В. Скорость торфонакопления в Западной Сибири // Динамика болотных экосистем : материалы симп. - Петрозаводск : Изд-во Карел. науч. центра РАН, 2000. - С. 56-59.

36. Левковская, Г. М. Палинологические данные к палеогеографии и хронологии культур каменного века на территории европейской части СССР, Сибири и сопредельных территорий / Г. М. Левковская // Первобытный человек, его материальная культура и природная среда в плейстоцене и голоцене. - М. : Изд-во ИГ АН CCCP, 1974. - C. 204-210.

37. Архипов, С. А. Палинологическая характеристика и абсолютный возраст торфяника в устье р. Томи / С. А. Архипов, М. Р. Вотах // Палинология Сибири. - М. : Наука, 1980. - С. 118-122.

38. Пьявченко, Н. И. О возрасте торфяников и сменах растительности на юге Западной Сибири в голоцене / Н. И. Пьявченко // Бюллетень комиссии по изучению четвертичного периода. -1985. - № 52. - С. 164-170.

39. Левина, Т. П. Климатические ритмы голоцена юга Западной Сибири / Т. П. Левина, Л. А. Орлова // Геология и геофизика. - 1993. - Т. 34, № 3. - С. 38-55.

40. Рябогина, Н. Е. Динамика растительности на границе подтаежной и лесостепной зон Зауралья в среднем и позднем голоцене (по материалам спорово-пыльцевого анализа торфяника Андреевского) // Современные проблемы популяционной, исторической и прикладной экологии : материалы конф. молодых ученых. Екатеринбург : ИЭРиЖ УрО РАН, 2001. - Вып. 2. - С. 211-215.

41. Якимов, А. С. Природные условия Туро-Пышминского междуречья в X-IV вв. до н.э. / А. С. Якимов, Н. Е. Рябогина, С. Н. Иванов // Вестник археологии, антропологии и этнографии. - 2007. - № 8. C. 206-225.

42. Зах, В. А. Эпоха бронзы Присалаирья (по материалам Изылинского микрорайона) / В. А. Зах. - Новосибирск : Наука, 1997. - 132 с.

43. Зах, В. А. Археологические исследования в Приишимье в 1997 году / В. А. Зах // Вестник археологии, антропологии и этнографии. - Тюмень, 1999. - Вып. 2. - С. 146-150.

44. Иванов, С. Н. Материалы палинологического исследования торфяника Станичный Рям / С. Н. Иванов, Н. Е. Рябогина // Проблемы взаимодействия человека и природной среды. - Тюмень : Изд-во ИПОС СО РАН, 2003. - Вып. 4. - С. 62-68.

45. Хазина, И. В. Растительность и климат в голоцене Юго-Восточной части Западной Сибири: по палинологическим данным : дис. ... канд. геол.-минерал. наук / Хазина И. В. - Новосибирск, 2008. - 124 с.

46. Большаник, П. В. Антропогенный фактор в развитии ландшафтов окуневского археологического микрорайона // Интеграция археологических и этнографических исследований : материалы VI Междунар. науч. семинара. - Омск, 1998. - Ч. 1. - С. 19-22.

47. Зыкина, В. С. Природа и климат второй половины голоцена в Сибири: Палеопедологические данные и результаты радиоуглеродного датирования / В. С. Зыкина, Л. А. Орлова // Проблемы реконструкции климата и природной среды голоцена и плейстоцена Сибири. - Новосибирск : Изд-во ИАЭТ СО РАН, 2000. Вып. 2. - С. 250-260.

48. Неолит Северной Евразии. Археология СССР. - М. : Наука, 1996. - 384 с.

49. Турубанова, С. А. Экологический сценарий истории формирования живого покрова Европейской России и сопредельных территорий на основе реконструкции ареалов ключевых видов животных и растений : дис. ... канд. биол. наук / Турубанова С. А. - М., 2002. - 199 с.

50. Зенин, В. Н. Поздний палеолит Западно-Сибирской равнины : дис. ... д-ра ист. наук / Зенин В. Н. - Новосибирск, 2003. - 432 с.

51. Авенариус, И. Г. Палеогеография Северной Евразии в позднем плейстоцене-голоцене и географический прогноз / И. Г. Авенариус, М. В. Муратова, И. И. Спасская. - М. : Наука, 1978. - 76 с.

52. Палеогеографическая основа современных ландшафтов. - М. : Наука, 1994. - 205 с.

53. Пучков, П. В. Некомпенсированные вюрмские вымирания. Сообщение 4. Старый Свет: смягченный кризис / П. В. Пучков // Вестник зоологии. - 1993. - № 1. - С. 63-70.

54. Пучков, П. В. Некомпенсированные вюрмские вымирания. Сообщение 5. Кризис в Палеарктике / П. В. Пучков // Вестник зоологии. - 1993. - № 4. - С. 59-66.

55. Нейштадт, М. И. О смене природных условий в средней тайге Западной Сибири в голоцене / М. И. Нейштадт // Палинология в СССР. - М. : Наука, 1976. - С. 156-162. 
56. Лаухин, С. А. Палеорастительность и палеоклиматы раннего интерстадиала зырянского оледенения бореальной зоны Западно-Сибирской равнины // Вестник археологии, антропологии и этнографии. - 2007. № 8. - C. 188-205.

57. Силантьева, М. М. Флора Алтайского края: Анализ и история формирования : дис. ... д-ра биол. наук / Силантьева М. М. - Барнаул, 2008. - 797 с.

58. Глебов, Ф. З. Динамика болотной и суходольной растительности и климата междуречья Оби и Васюгана в голоцене / Ф. З. Глебов, Л. В. Карпенко // Лесоведение. - 1999. - № 5. - С. 35-40.

59. Верещагин, Н. К. Ареалы копытных фауны СССР в антропогене / Н. К. Верещагин, Г. Ф. Барышников // Труды Зоологического института. - Л., 1980. - Т. 93. - С. 3-19.

60. Алексеева, Э. В. Млекопитающие плейстоцена юго-востока Западной Сибири : дис. ... канд. биол. наук / Алексеева Э. В. - Л., 1971. - 326 с.

61. Шпанский, А. В. Копытные среднего-позднего неоплейстоцена юго-востока Западно-Сибирской равнины (стратиграфическое значение, палеоэкология и палеозоогеография) : дис. ... канд. геол.-минерал. наук / Шпанский А. В. - Томск, 2000. - 231 с.

62. Величко, А. А. Природный процесс в плейстоцене / А. А. Величко. - М. : Наука, 1973. -256 с.

63. Украинцева, В. В. Растительность и климат Сибири эпохи мамонта / В. В. Украинцева // Труды государственного природного биосферного заповедника «Таймырский». - Красноярск, 2002. - Вып. 4. - 193 с.

64. Смирнов, Н. Г. Влияние хозяйственной деятельности древнего населения на экосистемы Западной Сибири и Зауралья / Н. Г. Смирнов, П. А. Косинцев, А. В. Бородин // Антропогенные факторы в истории развития современных экосистем. - М. : Наука, 1981. - С. 166-178.

65. Бородин, А. В. Млекопитающие плейстоцена севера Западной Сибири / А. В. Бородин, П. А. Косинцев // Мамонт и его окружение: 200 лет изучения. - М. : ГЕОС, 2001. - С. 244-252.

66. Пидопличко, И. Г. О ледниковом периоде. История четвертичной фауны европейской части СССР / И. Г. Пидопличко. - Киев : Наук. думка, 1954. - Вып. 3. - 220 с.

67. Ермолова, Н. М. Териофауна долины Ангары в позднем антропогене / Н. М. Ермолова. - Новосибирск : Наука, 1978. - 224 с.

68. Косинцев, П. А. Голоценовые остатки крупных млекопитающих Западной Сибири / П. А. Косинцев // Современное состояние и история животного мира Западно-Сибирской низменности. - Свердловск : Изд-во УрО АН СССР, 1988. - С. 32-51.

69. Буровский, А. М. Первая антропогенная перестройка биосферы / А. М. Буровский // Биосфера. - 2010. T. 2, № 1. - С. 29-45.

70. Лисицын, Н. Ф. О «трансконтинентальных» и «местных» миграциях в позднем палеолите южных районов Сибири / Н. Ф. Лисицын // Палеодемография и миграционные процессы в Западной Сибири в древности и средневековье. - Барнаул : Изд-во АлтГУ, 1994. - С. 27-29.

71. Аникович, М. В. Мамонт в культуре верхнего палеолита Восточной Европы и Северной Азии / М. В. Аникович, И. Е. Кузьмина // Пространство культуры в археолого-этнографическом измерении. Западная Сибирь и сопредельные территории : материалы XII Западно-Сибирской археол.-этнографич. конф. - Томск : Изд-во ТГУ, 2001. - 362 с.

72. Зах, В. А. Хроностратиграфия неолита и раннего металла лесного Тоболо-Ишимья : дис. ... д-ра ист. наук / Зах В. А. - Тюмень, 2006. - 364 с.

73. Старков, В. Ф. Хозяйство населения лесного Зауралья в эпоху неолита и энеолита / В. Ф. Старков // Антропогенные факторы в истории развития современных экосистем. - М. : Наука, 1981. - С. 131-148.

74. Волков, Е. Н. Комплекс древних и средневековых памятников «Ингальская долина» (Хронология культур, принципы взаимодействия человека и окружающей среды в контексте тематики изучения археологических микрорайонов) : дис. ... канд. ист. наук / Волков Е. Н. - Тюмень, 2005. - 267 с.

75. Пучков, П. В. Некомпенсированные вымирания в плейстоцене: предполагаемый механизм кризиса / П. В. Пучков. - Киев : Ин-т зоологии АН УССР, 1989. - 60 с.

76. Пидопличко, И. Г. О ледниковом периоде. Биологические и географические особенности европейских представителей четвертичной фауны / И. Г. Пидопличко. - Киев : Наук. думка, 1951. - Вып. 2. - 264 с.

77. Жегалло, В. И. Судьба мегафауны Голарктики в позднем антропогене / В. И. Жегалло, Н. Н. Каландадзе, Т. В. Кузнецова, А. С. Раутиан // Мамонт и его окружение: 200 лет изучения. - М. : ГЕОС, 2001. C. 287-306.

78. Нейштадт, М. И. История лесов и палеогеография СССР в голоцене / М. И. Нейштадт. - М. : Изд-во АН CCCP, 1957. - $404 \mathrm{c}$.

79. Елина, Г. А. Палеорастительность Карелии за последние 9500 лет / Г. А. Елина // Биогеография Карелии. Труды КНЦ РАН. Серия: биология. - Вып. 2. - Петрозаводск, 2001. - С. 27-37.

80. Эволюция экосистем Европы при переходе от плейстоцена к голоцену (24-8 тыс. л. н.) / отв. ред. А. К. Маркова, Т. ван Кольфсхотен. - М. : Товарищество научных изданий КМК, 2008. -556 с.

81. Мащенко, Е. Н. Луговское: «кладбище мамонтов» и стоянка человека / Е. Н. Мащенко // Химия и жизнь XXI век. - 2004. - № 2. - С. 18-22.

82. Харитоненков, М. А. Генезис лесостепей Западно-Сибирской равнины в свете современных представлений теоретической экологии / М. А. Харитоненков // Вестник Тверского государственного университета. Серия: Биология и экология. - 2010. - № 32. - С. 72-82. 
83. Харитоненков, М. А. Экологический сценарий формирования современной лесостепи (на примере Западно-Сибирской равнины) / М. А. Харитоненков // Ученые записки Казанского государственного университета. Серия: Естественные науки. - 2011. - Т. 153, кн. 3. - С. 183-197.

84. Кирюшин, Ю. Ф. Миграционные процессы в Верхнем Приобье в эпоху энеолита и в бронзовом веке / Ю. Ф. Кирюшин // Палеодемография и миграционные процессы в Западной Сибири в древности и средневековье : тез. докл. науч. конф. - Барнаул : Изд-во АлтГУ, 1994. - С. 56-58.

85. Кирюшин, Ю. Ф. Особенности формирования хозяйственных типов на юге Западной Сибири эпохи энеолита и ранней бронзы / Ю. Ф. Кирюшин // Система жизнеобеспечения традиционных обществ в древности и современности. Теория, методология, практика : материалы XI Западно-Сибирской археол.этнографич. конф. - Томск : Изд-во ТГУ, 1998. - С. 111-113.

86. Матющенко, В. И. Древняя история населения лесного и лесостепного Прииртышья (неолит и бронзовый век). Часть 3. Андроновская культура на Верхней Оби / В. И. Матющенко // Из истории Сибири. - Томск, 1973. - Вып. 11. - 150 с.

87. Потемкина, Т. М. Бронзовый век лесостепного Притоболья / Т. М. Потемкина. - М. : Наука, $1985 .-376$ с.

88. Эпоха бронзы лесной полосы СССР. Археология СССР / под ред. О. Н. Бадера, Д. А. Крайнова, М. Ф. Косарева. - М. : Наука, 1987. - 472 с.

89. Молодин, В. И. Археологические памятники Венгеровского района Новосибирской области / В. И. Молодин, А. В. Новиков. - Новосибирск : Наука, 1998. - 140 с.

90. Глумов, Г. А. К вопросу о влиянии хозяйственной деятельности на растительный покров Западной Сибири в период голоцена / Г. А. Глумов // Охрана окружающей среды. - Пермь, 1959. - С. 37-47.

91. Прохоров, Б. Б. Экология человека: эволюционный аспект / Б. Б. Прохоров // Эволюционная и историческая антропоэкология. - М. : Наука, 1994. - С. 47-59.

92. Косарев, М. Ф. Древние культуры Томско-Нарымского Приобья / М. Ф. Косарев. - М. : Наука, 1974. - 166 с.

93. Абрамова, М. Б. Красноозерская культура на Иртыше / М. Б. Абрамова, В. И. Стефанов // Археологические исследования в районах новостроек Сибири. - Новосибирск : Наука, 1985. - С. 103-130.

94. Зимина, О. Ю. К вопросу о переходном времени от бронзы к раннему железному веку в Западной Сибири (историографический аспект) / О. Ю. Зимина // Проблемы взаимодействия человека и природной среды. Тюмень : Изд-во ИПОС СО РАН, 2002. - Вып. 3. - С. 28-33.

95. Андреев, Ю. А. Влияние антропогенных и природных факторов на возникновение пожаров в лесах и населенных пунктах : дис. ... Д-ра техн. наук / Андреев Ю. А. - М., 2003. - 333 с.

96. Бородовский, А. П. Археологические памятники Искитимского района Новосибирской области. Материалы «Свода памятников истории и культуры народов России» / А. П. Бородовский. - Новосибирск, 2002. Вып. 6. - С. 81-83.

97. Зубаков, В. А. Палеогеография Западно-Сибирской низменности в плейстоцене и позднем плиоцене В. А. Зубаков. - Л. : Наука, 1972. - 270 с.

98. Чиндина, Л. А. Древняя история Среднего Приобья в эпоху железа. Кулайская культура / Л. А. Чиндина. Томск : Изд-во ТГУ, 1984. - 254 с.

99. Матвеева, Н. П. Ранний железный век Приишимья / Н. П. Матвеева. - Новосибирск : Наука, 1994. - 152 с.

100. Данченко, Е. М. Южнотаежное Прииртышье в середине - второй половине I тыс. до н.э. / Е. М. Данченко. Омск : Изд-во ОмГПУ, 1996. - 212 с.

101. Молодин, В. И. Археологические памятники Колыванского района Новосибирской области / В. И. Молодин, А. П. Бородовский, Т. Н. Троицкая. - Новосибирск : Наука, 1996. - 192 с.

102. Могильников, В. А. Население Верхнего Приобья в середине - второй половине I тысячелетия до н.э. / В. А. Могильников. - М. : Наука, 1997. - 196 с.

103. Матвеева, Н. П. Социальное развитие народов западносибирской лесостепи в раннем железном веке / Н. П. Матвеева // Сибирь в панораме тысячелетий : материалы Междунар. симп. - Новосибирск, 1998. T. 1. - C. 359-366.

104. Матвеева, Н. П. Материалы к палеодемографической характеристике саргатской общности / Н. П. Матвеева // Вестник археологии, антропологии и этнографии. -1999. - Вып. 2. - С. 87-96.

105. Могильников, В. А. Угры и самодийцы Урала и Западной Сибири / В. А. Могильников // Археология СССР. Финно-угры и балты в эпоху средневековья. - М. : Наука, 1987. - С. 163-235.

106. Чиндина, Л. А. История Среднего Приобья в эпоху раннего средневековья (рёлкинская культура) / Л. А. Чиндина. - Томск : Изд-во ТГУ, 1991. - 184 с.

107. Могильников, В. А. Особенности этнокультурного развития в степном и лесостепном междуречье Иртыша и Оби во второй половине I - начале II тыс. н.э. / В. А. Могильников // Интеграция археологических и этнографических исследований. - М. ; Омск : Изд-во ОмГу, 1999. - С. 38-41.

108. Коников, Б. А. Таёжное Прииртышье в Х-ХІІІ вв. н.э. / Б. А. Коников. - Омск : Изд-во ОмГПУ, 1993. - 223 с.

109. Адамов, А. А. Тюркские древности Новосибирского Приобья / А. А. Адамов // Тюркские народы : материалы V Сиб. симп. «Культурное наследие народов Западной Сибири». - Тобольск ; Омск : ОмГПУ, 2002. C. $12-16$.

110. Бояршинова, 3. Я. Население Западной Сибири до начала русской колонизации / 3. Я. Бояршинова. Томск : Изд-во ТГУ, 1960. - 191 с.

111. Коников, Б. А. Омское Прииртышье в эпоху средневековья / Б. А. Коников. - Омск : Наука, $2005 .-244$ с. 
112. Матвеева, Н. П. Расселение саргатских племен в Прииртышье / Н. П. Матвеева // Проблемы взаимодействия человека и природной среды. - Тюмень : Изд-во ИПОС СО РАН, 2001. - Вып. 2. - С. 39-43.

113. Паллас, П. С. Путешествие по разным местам Российского государства / П. С. Паллас. - СПб. : Изд-во Императорской академии наук, 1786. - Ч. 2, кн. 2. - 571 с.

114. Список населённых мест. Тобольская губерния. По сведениям 1868-1869 годов. - СПб. : Изд-во Центрального статистического комитета МВД, 1871. - Т. 60. - 196 с.

115. Энгельфельд, В. А. О лесах Западной Сибири. 1-е приложение к «Лесному журналу» за 1888 г. / В. А. Энгельфельд. - СПб. : Изд-во Лесного общества, 1888. - 71 с.

116. Гордягин, А. Я. Материалы для познания почв и растительности Западной Сибири. Ч. 2 / А. Я. Гордягин // Труды общества естествоиспытателей при Казанском университете. - Казань, 1901. - Т. 35, вып. 2. C. 223-528.

117. Танфильев, Г. И. Бараба и Кулундинская степь в пределах Алтайского округа / Г. И. Танфильев // Труды Геологической части кабинета Его Императорскаго Величества. - 1902. - Т. 5, вып. І. - С. 59-319.

118. Рубчевский, В. Н. Леса и население Завасюганья (Из путевых заметок лесничего) / В. Н. Рубчевский. Томск : Тип. Губ. упр., 1909. - 70 с.

119. Карта Западной Сибири с показанием лесов. М 1: 200 вер. // Памятная книжка Западной Сибири. - Омск : Картографическое заведение Ильина, 1882. - 406 с.

120. Харитоненков, М. А. Преобразование лесного покрова юга Западно-Сибирской равнины в XVII-XIX вв. в результате ее освоения переселенцами / М. А. Харитоненков // Лесоведение. - 2012. - № 5. - С. $29-35$.

121. История Сибири с древнейших времен до наших дней : в 5 т. Т. 3. Сибирь в эпоху капитализма / под ред. А. П. Окладникова. - Л. : Наука, 1968. - 532 с.

122. Крестьянство Сибири в эпоху феодализма / под ред. А. П. Окладникова. - Новосибирск : Наука, $1982 .-$ $502 \mathrm{c}$.

123. Крестьянство Сибири в эпоху капитализма / под ред. Л. М. Горюшкина. - Новосибирск : Наука, 1983. $400 \mathrm{c}$.

124. Шунков, В. И. Очерки по истории земледелия Сибири (XVII в.) / В. И. Шунков. - М. : Изд-во АН СССР, 1956. $-432 \mathrm{c}$.

125. Шенников, А. А. Земледельческая неполная оседлость и «теория бродяжничества» / А. А. Шенников // Этнография народов СССР. - Л. : Наука, 1971. - С. 76-93.

126. Жилина, Т. Н. Западная Сибирь в Малый ледниковый период (1550-1850 гг.): природа и русская колонизация : дис. ... канд. геогр. наук / Жилина Т. Н. - Томск, 2004. - 161 с.

127. Асалханов, И. А. Сельское хозяйство Сибири конца XIX - начала XX в. / И. А. Асалханов. - Новосибирск : Наука. Сиб. отд-ние, 1975. - 267 с.

128. Власова, И. В. Источники для изучения земледельческого опыта русского населения Сибири XVII-XVIII вв. / И. В. Власова // Земледельческое освоение Сибири в конце XVII - начале XX в. - Новосибирск : Наука, 1985. - С. 19-31.

129. Скалозубов, Н. Л. Обзор Тобольской губернии в сельскохозяйственном отношении за 1900 год / Н. Л. Скалозубов, П. А. Грабовский. - Тобольск : Губернская типография, 1901. - 52 с.

130. Бочанова, Г. А. Промысловое освоение Сибири в конце XIX - начале XX в. (вопросы экологии) / Г. А. Бочанова // Земледельческое освоение Сибири в конце XVII - начале XX в. - Новосибирск : Наука, 1985. C. $129-150$.

131. Туров, С. В. Крестьянские деревообрабатывающие промыслы и состояние лесов Зауралья в XVIII - первой трети XIX вв. / С. В. Туров // Уральский сборник. История. Культура. Религия. - Екатеринбург : Изд-во УрГУ, 1997. - Вып. 1. - С. 163-168.

132. В. Э. К вопросу о крестьянских лесах в Западной Сибири / В. Э. // Лесной журнал. - 1887. - Вып. 5. C. $606-613$.

133. Строгий, А. А. Истребление лесов в Сибири и необходимость Сибирского лесоохранительного закона. (Доклад Всероссийскому Съезду лесовладельцев и лесохозяев в СПб. для обсуждения Лесоохранительного закона) / А. А. Строгий. - СПб. : Тип. СПб. Градоначальства, 1911. - 24 с.

134. Крылов, Г. В. Леса Западной Сибири / Г. В. Крылов. - М. : Изд-во АН СССР, 1961. - 255 с.

135. Ильина, И. С. Растительный покров Западно-Сибирской равнины / И. С. Ильина, Е. И. Лапшина, Н. Н. Лавренко. - Новосибирск : Наука, 1985. - 251 с.

\section{References}

1. Antipina E. E., Maslov S. P. Jevoljucionnaja i istoricheskaja antropojekologija [Evolutionary and Historic Anthropo-ecology]. Moscow: Nauka, 1994, pp. 111-120.

2. Kaljakin V. N. Mlekopitajushhie v nazemnyh jekosistemah [Mammals in Ground Ecosystems]. Moscow: Nauka, 1985, pp. 67-99.

3. Puchkov P. V. Vestnik zoologii [Zoology News]. 1991, no. 5, pp. 45-53.

4. $\quad$ Puchkov P. V. Vestnik zoologii [Zoology News]. 1992, no. 1, pp. 58-66.

5. Puchkov P. V. Vestnik zoologii [Zoology News]. 1992, no. 4, pp. 73-80. 
6. Olff H., Vera F. W. M., Bokdam J., Bakker E. S., Gleichmann J. M., Maeyer de K., Smit R. Plant biol. 1999 , vol. 1, pp. 1-11.

7. Smirnova O. V., Kaljakin V. N., Turubanova S. A., Bobrovskij M. V. Mamont i ego okruzhenie: 200 let izuchenija [Mammoth and Its Environment: 200 Years of Study]. Moscow: GEOS, 2001, pp. 200-208.

8. Smirnova O. V., Bakun E. Ju., Turubanova S. A. Lesovedenie [Forest Studies]. 2006, no. 1, pp. 23-33.

9. Gorshkov V. G., Makar'eva A. M. Hydrology and Earth System Sciences. 2007, no. 11, pp. 1013-1033.

10. Doughty C. E., Wolf A., Field C. B. Geophys. Res. Lett. 2010, vol. 37, 5 p.

11. Orlova L. A., Levina T. P. Jevoljucija klimata, bioty i sredy obitanija cheloveka v pozdnem kajnozoe Sibiri [Evolution of Climate, Biotas and Human Environment in Late Cenozoic Era in Siberia]. Novosibirsk: Izd-vo SO RAN, 1991, pp. 72-78.

12. Zykin V. S., Zykina V. S., Orlova L. A., Krukover A. A., Foronova I. V. Problemy rekonstrukcii klimata i prirodnoj sredy golocena i plejstocena Sibiri [Problems of Climate and Environment Reconstruction during the Holocene and the Pleistocene in Siberia]. Novosibirsk: Izd-vo IAJeT SO RAN, 1998, pp. 175-191.

13. Rjabogina N. E., Semochkina T. G., Larin S. I. Jekologija drevnih i sovremennyh obshhestv [Ecology of Ancient and Modern Societies]. Tjumen: Izd-vo IPOS SO RAN, 1999, pp. 61-63.

14. Bolihovskaja N. S., Gunova B. C., Sobolev V. M. Mamont i ego okruzhenie: 200 let izuchenija [Mammoth and Its Environment: 200 Years of Study]. Moscow: GEOS, 2001, pp. 168-187.

15. Volkova V. S., Gnibidenko Z. N., Gorjacheva A. A. Osnovnye zakonomernosti global'nyh i regional'nyh izmenenij klimata i prirodnoj sredy v pozdnem kajnozoe Sibiri [Major Regularities of Global and Regional Climate Changes in Late Cenozoic Era in Siberia]. Novosibirsk, 2002, iss. 1, pp. 48-57.

16. Troickij S. L. Problemy stratigrafii i paleogeografii plejstocena Sibiri [Problems of Stratigraphy and Planigraphy of the Pleistocene in Siberia]. Novosibirsk: Nauka, 1982, pp. 7-10.

17. Dinesman L. G. Paleoklimaty pozdnelednikov'ja i golocena [Paleoclimates of Late Glacial and the Holocene Periods]. Moscow: Nauka, 1989, pp. 48-51.

18. Val'ter G. Obshhaja geobotanika [General Geo-Botany]. Moscow: Mir, 1982, 261 p.

19. Konovalov A. A., Ivanov S. N. Jekologija drevnih i sovremennyh obshhestv: tez. dokl. konf. [Ecology of Ancient and Modern Societies: Conference Report Abstracts]. Tjumen: Izd-vo IPOS SO RAN, 2003, iss. 2, pp. 53-56.

20. Altuhov Ju. P. Geneticheskie processy v populjacijah [Genetic Processes in Populations]. Moscow: Nauka, 1983, $179 \mathrm{p}$.

21. Zavadskij K. M. Vid i vidoobrazovanie [Species and Species Formation]. Leningrad: Nauka, 1968,404 p.

22. Monin A. S. Istorija Zemli [History of the Earth]. Leningrad: Nauka, 1977, 228 p.

23. Chumichjov S. A. Al'manah civilizacionnyh issledovanij. Novaja Paradigma 1 (Hozhenie v Ojkumenu) [Almanac of Civilization Studies. New Paradigm]. 2003. Available at: www.newchrono.ru/frame1/Publ/CLIMATE.htm

24. Vostochnoevropejskie lesa: istorija v golocene $i$ sovremennost' [East-European Forests: History in the Holocene and Present]. Red. resp. O. V. Smirnova. Moscow: Nauka, 2004, bk. 1, 479 p.; bk. 2, 575 p.

25. Smirnova O. V., Bobrovskij M. V., Hanina L. G., Smirnov V. Je. Uspehi sovremennoj biologii [Achievements in Current Biolgy]. 2006, vol. 126, no. 1, pp. 27-49.

26. Smirnova O. V., Toropova N. A. Uspehi sovremennoj biologii [Achievements in Current Biology]. 2008, vol. 128, no. 2, pp. 129-144.

27. Monitoring biologicheskogo raznoobrazija lesov Rossii: metodologija i metody [Monitoring of Bio-Diversity of Forests in Russia: Methodology and Methods]. Red. resp. A. S. Isaev. Moscow: Nauka, 2008, 453 p.

28. Hotinskij N. A. Golocen Severnoj Evrazii [The Holocene in Northern Eurasia]. Moscow: Nauka, 1977,200 p.

29. Bljaharchuk T. A. Istorija rastitel'nosti jugo-vostoka Zapadnoj Sibiri v golocene po dannym sporovopyl'cevogo $i$ botanicheskogo analiza torfa: dis. kand. biol. nauk [History of Plant Life in South-Eastern Siberia in the Holocene, Based on Spore/Pollen Botanic Analysis of Peat: Research Thesis]. Tomsk, 1989, 248 p.

30. Orlova L. A. Golocen Baraby. Stratigrafija i radiouglerodnaja hronologija [The Holocene in the Baraba Steppe. Stratigraphy and Radiocarbon Chronography]. Novosibirsk: Nauka, 1990, 128 p.

31. Bolotnye sistemy Zapadnoj Sibiri i ih prirodoohrannoe znachenie [Swamp Systems in West Siberia and their Importance in Nature Preservation]. Ed. by V. B. Kuvaev. Tula: Grif i K , 2001, 584 p.

32. Rjabogina N. E. Stratigrafija golocena juzhnogo Zaural'ja, izmenenie landshaftno-klimaticheskih uslovij obitanija drevnego cheloveka: dis. kand. geol.-mineral. nauk [Holocene Stratification in the South of the Trans-Urals. Changes of Landscape and Climate Conditions of Ancient Humans Environment]. Tjumen, 2004, $419 \mathrm{p}$.

33. Haritonenkov M. A. Rol' antropogennogo faktora v formirovanii rastitel'nogo pokrova juga Zapadno-Sibirskoj ravniny $v$ jepohu tradicionnogo prirodopol'zovanija (s pozdnego paleolita do konca XIX v.): dis. kand. biol. nauk [Role of Anthropogenic Factor in Forming Vegetation Layer in the South of West-Siberian Plain in the Era of Traditional Nature Use (from the Late Paleolithic Untill the End of $19^{\text {th }}$ c.): Research Thesis]. Moscow, 2012, 308 p.

34. Bukreeva G. F., Levkovskaja G. M. Problemy rekonstrukcii klimata i prirodnoj sredy golocena i plejstocena Sibiri [Reconstructing the Climate and Environment of the Holocene and the Pleistocene in Siberia]. Novosibirsk, 2000, iss. 2, pp. 48-56.

35. Vasil'ev S. V. Dinamika bolotnyh jekosistem: materialy simp. [Swamp Ecosystem Dynamics]. Petrozavodsk: Izdvo Karel. nauch. centra RAN, 2000, pp. 56-59.

36. Levkovskaja G. M. Pervobytnyj chelovek, ego material'naja kul'tura i prirodnaja sreda v plejstocene $i$ golocene [Pre-Historic Human, Its Material Culture and Natural Environment in the Pleistocene and the Holocene]. Moscow: Izd-vo IG AN SSSR, 1974, pp. 204-210. 
37. Arhipov S. A., Votah M. R. Palinologija Sibiri [Siberian Palynology]. Moscow: Nauka, 1980, pp. 118-122.

38. P'javchenko N. I. Bjulleten' komissii po izucheniju chetvertichnogo perioda [Reports of the Committee on Quaternary Period Studies]. 1985, no. 52, pp. 164-170.

39. Levina T. P., Orlova L. A. Geologija i geofizika [Geology and Geophysics]. 1993, vol. 34, no. 3, pp. 38-55.

40. Rjabogina N. E. Sovremennye problemy populjacionnoj, istoricheskoj i prikladnoj jekologii: materialy konf. molodyh uchenyh [Current Issues in Population, Historical and Applied Ecology: Conference Papers of the Young Scientists Conference]. Ekaterinburg: IJeRiZh UrO RAN, 2001, iss. 2, pp. 211-215.

41. Jakimov A. S., Rjabogina N. E., Ivanov S. N. Vestnik arheologii, antropologii i jetnografii [Archeology, Anthropology and Ethnography News]. 2007, no. 8, pp. 206-225.

42. Zah V. A. Jepoha bronzy Prisalair'ja (po materialam Izylinskogo mikrorajona) [Bronze Age in the Area of Salair Ridge (Izylinsk District)]. Novosibirsk: Nauka, 1997, 132 p.

43. Zah V. A. Vestnik arheologii, antropologii i jetnografii [Archeology, Anthropology and Ethnography News]. Tjumen, 1999, iss. 2, pp. 146-150.

44. Ivanov S. N., Rjabogina N. E. Problemy vzaimodejstvija cheloveka $i$ prirodnoj sredy [Problems of HumanEnvironment Interaction]. Tjumen: Izd-vo IPOS SO RAN, 2003, iss. 4, pp. 62-68.

45. Hazina I. V. Rastitel'nost' i klimat v golocene Jugo-Vostochnoj chasti Zapadnoj Sibiri: po palinologicheskim dannym: dis. kand. geol.-mineral. nauk [Vegetation and Climate in the Holocene of the South-East of West Siberia: on the Basis of Palynology Data]. Novosibirsk, 2008, 124 p.

46. Bol'shanik P. V. Integracija arheologicheskih i jetnograficheskih issledovanij: materialy VI Mezhdunar. nauch. Seminara [Integration of Archeological and Ethnographic Studies: VI International Research Seminar]. Omsk, 1998, part 1, pp. 19-22.

47. Zykina V. S., Orlova L. A. Problemy rekonstrukcii klimata i prirodnoj sredy golocena i plejstocena Sibiri [Problems of Climate and Environment Reconstruction during the Holocene and the Pleistocene in Siberia]. Novosibirsk: Izd-vo IAJeT SO RAN, 2000, iss. 2, pp. 250-260.

48. Neolit Severnoj Evrazii. Arheologija SSSR [Neolithic Age in Eurasia. Archeology in USSR]. Moscow: Nauka, 1996, $384 \mathrm{p}$.

49. Turubanova S. A. Jekologicheskij scenarij istorii formirovanija zhivogo pokrova Evropejskoj Rossii i sopredel'nyh territorij na osnove rekonstrukcii arealov kljuchevyh vidov zhivotnyh i rastenij: dis. kand. biol. nauk [Ecological Scenario of the History of Living Cover in European Russia and Neighbouring Regions on the Basis of Reconstructing the Habitat of Key Animal and Plant Species]. Moscow, 2002, 199 p.

50. Zenin V. N. Pozdnij paleolit Zapadno-Sibirskoj ravniny: dis. d-ra ist. nauk [Late Paleolithic in West-Siberian Plain: Higher Doctorate Thesis]. Novosibirsk, 2003, 432 p.

51. Avenarius I. G., Muratova M. V., Spasskaja I. I. Paleogeografija Severnoj Evrazii v pozdnem plejstocenegolocene i geograficheskij prognoz [Paleogeography in Northern Eurasia in Late Pleistocene-Holocene and Geographical Forecast]. Moscow: Nauka, 1978, 76 p.

52. Paleogeograficheskaja osnova sovremennyh landshaftov [Paleogeography Basis of Modern Landscapes]. Moscow: Nauka, 1994, 205 p.

53. Puchkov P. V. Vestnik zoologii [Zoology News]. 1993, no. 1, pp. 63-70.

54. Puchkov P. V. Vestnik zoologii [Zoology News]. 1993, no. 4, pp. 59-66.

55. Nejshtadt M. I. Palinologija v SSSR [Palynology in USSR]. Moscow: Nauka, 1976, pp. 156-162.

56. Lauhin S. A. Vestnik arheologii, antropologii i jetnografii [Archeology, Anthropology and Ethnography News]. 2007, no. 8, pp. 188-205.

57. Silant'eva M. M. Flora Altajskogo kraja: Analiz i istorija formirovanija: dis. d-ra biol. nauk [Flora of Altai Region: Analysis and History of Development: Higher Doctorate Research Thesis]. Barnaul, 2008, 797 p.

58. Glebov F. Z., Karpenko L. V. Lesovedenie [Forest Studies]. 1999, no. 5, pp. 35-40.

59. Vereshhagin N. K., Baryshnikov G. F. Trudy Zoologicheskogo instituta [Zoological Institute Proceedings]. Leningrad, 1980, vol. 93, pp. 3-19.

60. Alekseeva Je. V. Mlekopitajushhie plejstocena jugo-vostoka Zapadnoj Sibiri: dis. kand. biol. nauk [Mammals in the Pleistocene of the South-East of West Siberia]. Leningrad, 1971, 326 p.

61. Shpanskij A. V. Kopytnye srednego-pozdnego neoplejstocena jugo-vostoka Zapadno-Sibirskoj ravniny (stratigraficheskoe znachenie, paleojekologija i paleozoogeografija): dis. kand. geol.-mineral. nauk [Hoofed Mammals of Middle and Late Neo-Pleistocene of the South-East of West-Siberian Plain (Stratigraphy Meaning, Paleoecology, Paleo-Zoo-Geography)]. Tomsk, 2000, 231 p.

62. Velichko A. A. Prirodnyj process v plejstocene [Nature Process in the Pleistocene]. Moscow: Nauka, 1973,256 p.

63. Ukrainceva V. V. Trudy gosudarstvennogo prirodnogo biosfernogo zapovednika «Tajmyrskij» [State Biosphere Reserve 'Taymyr' Proceedings]. Krasnojarsk, 2002, iss. 4, 193 p.

64. Smirnov N. G., Kosincev P. A., Borodin A. V. Antropogennye faktory v istorii razvitija sovremennyh jekosistem [Anthropogenic Factors in the History of Development of Present Ecosystems.]. Moscow: Nauka, 1981, pp. 166178.

65. Borodin A. V., Kosincev P. A. Mamont i ego okruzhenie: 200 let izuchenija [Mammoth and Its Environment: 200 Years of Study]. Moscow: GEOS, 2001, pp. 244-252.

66. Pidoplichko I. G. O lednikovom periode. Istorija chetvertichnoj fauny evropejskoj chasti SSSR [On Ice Age. History of Quaternary Fauna in European Part of USSR]. Kiev: Nauk. dumka, 1954, iss. 3, 220 p. 
67. Ermolova N. M. Teriofauna doliny Angary v pozdnem antropogene [Theriofauna of Angara Valley in Late Quaternary Period]. Novosibirsk: Nauka, 1978, 224 p.

68. Kosincev P. A. Sovremennoe sostojanie i istorija zhivotnogo mira Zapadno-Sibirskoj nizmennosti [Current State and History of Animal Life in West-Siberian Plain]. Sverdlovsk: Izd-vo UrO AN SSSR, 1988, pp. 32-51.

69. Burovskij A. M. Biosfera [Biosphere]. 2010, vol. 2, no. 1, pp. 29-45.

70. Lisicyn N. F. Paleodemografija i migracionnye processy v Zapadnoj Sibiri v drevnosti i srednevekov'e [Paleodemography and Migration Processes in West Siberia in Ancient Times and the Middle Ages]. Barnaul: Izd-vo AltGU, 1994, pp. 27-29.

71. Anikovich M. V., Kuz'mina I. E. Prostranstvo kul'tury v arheologo-jetnograficheskom izmerenii. Zapadnaja Sibir' i sopredel'nye territorii: materialy XII Zapadno-Sibirskoj arheol.-jetnografich. konf. [Culture Space in Archeological and Ethnographical Dimension. West Siberia and Nearby Territories: Conference Papers of XII WestSiberia Archeology and Ethnography Conference]. Tomsk: Izd-vo TGU, 2001, 362 p.

72. Zah V. A. Hronostratigrafija neolita i rannego metalla lesnogo Tobolo-Ishim'ja: dis. d-ra ist. nauk [Chronological Stratigraphy of Neolithic Age and Early Metal Age in Forests of Tobol-Ishim Region]. Tjumen, 2006, 364 p.

73. Starkov V. F. Antropogennye faktory v istorii razvitija sovremennyh jekosistem [Anthropogenic Factors in the History of Development of Present Ecosystems]. Moscow: Nauka, 1981, pp. 131-148.

74. Volkov E. N. Kompleks drevnih i srednevekovyh pamjatnikov «Ingal'skaja dolina» (Hronologija kul'tur, principy vzaimodejstvija cheloveka i okruzhajushhej sredy v kontekste tematiki izuchenija arheologicheskih mikrorajonov): dis. kand. ist. nauk [Complex of Ancient and Medieval Monuments in "Ingala Valley" (Chronology of Cultures, Principles of Human-Environment Interaction in the Context of Studying Archeology of Small Regions)]. Tjumen, 2005, 267 p.

75. Puchkov P. V. Nekompensirovannye vymiranija v plejstocene: predpolagaemyj mehanizm krizisa [Unbalanced Extinction in the Pleistocene: Possible Crisis Mechanism]. Kiev: In-t zoologii AN USSR, 1989, 60 p.

76. Pidoplichko I. G. O lednikovom periode. Biologicheskie i geograficheskie osobennosti evropejskih predstavitelej chetvertichnoj fauny [On Ice Age. Biological and Geographical Features of European Quaternary Period Fauna]. Kiev: Nauk. dumka, 1951, iss. 2, 264 p.

77. Zhegallo V. I., Kalandadze N. N., Kuznecova T. V., Rautian A. S. Mamont i ego okruzhenie: 200 let izuchenija [Mammoth and Its Environment: 200 Years of Study]. Moscow: GEOS, 2001, pp. 287-306.

78. Nejshtadt M. I. Istorija lesov i paleogeografija SSSR v golocene [Forest History and USSR Paleography]. Moscow: Izd-vo AN SSSR, 1957, 404 p.

79. Elina G. A. Biogeografija Karelii. Trudy KNC RAN. Serija: biologija [Forest History and USSR Paleography. Pro ceedings ]. Issue 2. Petrozavodsk, 2001, pp. 27-37.

80. Jevoljucija jekosistem Evropy pri perehode ot plejstocena $k$ golocenu (24-8 tys. l. n.) [Evolution of Ecosystems in Europe in the Transition from the Pleistocene to the Holocene]. Reds. resp. A. K. Markova, T. van Kol'fshoten. Moscow: Tovarishhestvo nauchnyh izdanij KMK, 2008, 556 p.

81. Mashhenko E. N. Himija i zhizn' - XXI vek [Chemistry and Life]. 2004, no. 2, pp. 18-22.

82. Haritonenkov M. A. Vestnik Tverskogo gosudarstvennogo universiteta. Serija: Biologija i jekologija [News of Tver State University. Series: Biology and Ecology]. 2010, no. 32, pp. 72-82.

83. Haritonenkov M. A. Uchenye zapiski Kazanskogo gosudarstvennogo universiteta. Serija: Estestvennye nauki [Kazan State University Proceedings. Series: Natural Sciences]. 2011, vol. 153, bk. 3, pp. 183-197.

84. Kirjushin Ju. F. Paleodemografija i migracionnye processy v Zapadnoj Sibiri v drevnosti i sredne-vekov'e: tez. dokl. nauch. konf. [Paleo-Demography and Migration Processes in West Siberia in Ancient Times and the Middle Ages: Conference Abstracts]. Barnaul: Izd-vo AltGU, 1994, pp. 56-58.

85. Kirjushin Ju. F. Sistema zhizneobespechenija tradicionnyh obshhestv v drevnosti i sovremennosti. Teorija, metodologija, praktika: materialy XI Zapadno-Sibirskoj arheol.-jetnografich. konf. [Life Support Facilities in Traditional Societies in Ancient Times and the Present. Theory, Methodology, Practice: Conference Papers of XI West Sibera Archeology and Ethnography Conference]. Tomsk: Izd-vo TGU, 1998, pp. 111-113.

86. Matjushhenko V. I. Iz istorii Sibiri [From the History of Siberia]. Tomsk, 1973, iss. 11, 150 p.

87. Potemkina T. M. Bronzovyj vek lesostepnogo Pritobol'ja [Bronze Age in Forests and Steppe near Tobol]. Moscow: Nauka, 1985, 376 p.

88. Jepoha bronzy lesnoj polosy SSSR. Arheologija SSSR [Bronze Age in Forest Zones of USSR. Archeology in USSR]. Eds. O. N. Badera, D. A. Krajnov, M. F. Kosarev. Moscow: Nauka, 1987, 472 p.

89. Molodin V. I., Novikov A. V. Arheologicheskie pamjatniki Vengerovskogo rajona Novosibirskoj oblasti [Archeological Monuments of Vengerov District in Novosibirsk Region]. Novosibirsk: Nauka, 1998, 140 p.

90. Glumov G. A. Ohrana okruzhajushhej sredy [Environment Protection]. Perm, 1959, pp. 37-47.

91. Prohorov B. B. Jevoljucionnaja i istoricheskaja antropojekologija [Evolutionary and Historic Antrhopoecology]. Moscow: Nauka, 1994, pp. 47-59.

92. Kosarev M. F. Drevnie kul'tury Tomsko-Narymskogo Priob'ja [Ancient Cultures in Tomsk-Narym Ob Region]. Moscow: Nauka, 1974, 166 p.

93. Abramova M. B., Stefanov V. I. Arheologicheskie issledovanija v rajonah novostroek Sibiri [Archeological Studies in Siberian New Housing Development Regions]. Novosibirsk: Nauka, 1985, pp. 103-130.

94. Zimina O. Ju. Problemy vzaimodejstvija cheloveka i prirodnoj sredy [Problems of Human-Environment Interaction]. Tjumen: Izd-vo IPOS SO RAN, 2002, iss. 3, pp. 28-33. 
95. Andreev Ju. A. Vlijanie antropogennyh i prirodnyh faktorov na vozniknovenie pozharov $v$ lesah $i$ nase-lennyh punktah: dis. d-ra tehn. nauk [Anthropogenic and Natural Impact on Wildfires and Urban Fires: Research Thesis: Higher Doctorate Thesis]. Moscow, 2003, 333 p.

96. Borodovskij A. P. Arheologicheskie pamjatniki Iskitimskogo rajona Novosibirskoj oblasti. Materialy «Svoda pamjatnikov istorii $i$ kul'tury narodov Rossii» [Archaeological Monuments of Iskitim Distrct in Novosibirsk Region]. Novosibirsk, 2002, iss. 6, pp. 81-83.

97. Zubakov V. A. Paleogeografija Zapadno-Sibirskoj nizmennosti v plejstocene i pozdnem pliocene [Paleography of West-Siberian Plain in the Pleistocene and the Late Pliocene]. Leningrad: Nauka, 1972, $270 \mathrm{p}$.

98. Chindina L. A. Drevnjaja istorija Srednego Priob'ja v jepohu zheleza. Kulajskaja kul'tura [Ancient History of Middle Ob Region in Iron Age. Kulaj Culture]. Tomsk: Izd-vo TGU, 1984, 254 p.

99. Matveeva N. P. Rannij zheleznyj vek Priishim'ja [Early Iron Age in Ishim District]. Novosibirsk: Nauka, 1994, $152 \mathrm{p}$.

100. Danchenko E. M. Juzhnotaezhnoe Priirtysh'e v seredine - vtoroj polovine I tys. do n.je. [Southern Taiga of the Irtysh Region in the Middle-Second Half of the $1^{\text {st }}$ Millenium BC]. Omsk: Izd-vo OmGPU, 1996, 212 p.

101. Molodin V. I., Borodovskij A. P., Troickaja T. N. Arheologicheskie pamjatniki Kolyvanskogo rajona Novosibirskoj oblasti [Archeological Monuments of Kolyvan District in Novosibirsk Region]. Novosibirsk: Nauka, 1996, $192 \mathrm{p}$.

102. Mogil'nikov V. A. Naselenie Verhnego Priob'ja v seredine-vtoroj polovine I tysjacheletija do n.je. [Altai District of the $\mathrm{Ob}$ - Settlements in the Middle-Second Half of the $1^{\text {st }}$ Millenium BC ]. Moscow: Nauka, 1997, $196 \mathrm{p}$.

103. Matveeva N. P. Sibir'v panorame tysjacheletij: materialy Mezhdunar. simp. [Siberia in Millennia Perspective: International Symposium]. Novosibirsk, 1998, vol. 1, pp. 359-366.

104. Matveeva N. P. Vestnik arheologii, antropologii i jetnografii [Archeology, Anthropology and Ethnography News]. 1999, iss. 2, pp. 87-96.

105. Mogil'nikov V. A. Arheologija SSSR. Finno-ugry i balty v jepohu srednevekov'ja [Archeology in USSR. FinnoUgric and Baltics Peoples in the Middle Ages]. Moscow: Nauka, 1987, pp. 163-235.

106. Chindina L. A. Istorija Srednego Priob'ja v jepohu rannego srednevekov'ja (rjolkinskaja kul'tura) [History of the Central Ob Region in Early Middle Ages]. Tomsk: Izd-vo TGU, 1991, 184 p.

107. Mogil'nikov V. A. Integracija arheologicheskih i jetnograficheskih issledovanij [Integration of Archeological and Ethnographic Research]. Moscow; Omsk: Izd-vo OmGu, 1999, pp. 38-41.

108. Konikov B. A. Tajozhnoe Priirtysh'e $v$ X-XIII vv. n.je. [Taiga of Irtysh Region in the 10th-13 ${ }^{\text {th }} \mathrm{cc}$.]. Omsk: Izd-vo OmGPU, 1993, 223 p.

109. Adamov A. A. Tjurkskie narody: mate-rialy V Sib. simp. «Kul'turnoe nasledie narodov Zapadnoj Sibiri» [Turkic Peoples: Proceedings of the $5^{\text {th }}$ Siberian Symposium 'Cultural Heritage of West Siberia Peoples]. Tobolsk; Omsk: OmGPU, 2002, pp. 12-16.

110. Bojarshinova Z. Ja. Naselenie Zapadnoj Sibiri do nachala russkoj kolonizacii [West Siberia People Before Russian Colonization]. Tomsk: Izd-vo TGU, 1960, $191 \mathrm{p}$.

111. Konikov B. A. Omskoe Priirtysh'e v jepohu srednevekov'ja [Omsk Irtysh in the Middle Ages]. Omsk: Nauka, 2005, 244 p.

112. Matveeva N. P. Problemy vzaimodejstvija cheloveka i prirodnoj sredy [Problems of Human-Environment Communication]. Tjumen: Izd-vo IPOS SO RAN, 2001, iss. 2, pp. 39-43.

113. Pallas P. S. Puteshestvie po raznym mestam Rossijskogo gosudarstva [Travelling through Different Regions of Russia]. Saint-Petersburg: Izd-vo Im-peratorskoj akademii nauk, 1786, part 2, bk. 2, 571 p.

114. Spisok naseljonnyh mest. Tobol'skaja gubernija. Po svedenijam 1868-1869 godov [Settlements List. Tobol Governorate. 1868-1869 data]. Saint-Petersburg: Izd-vo Central'-nogo statisticheskogo komiteta MVD, 1871, vol. 60, $196 \mathrm{p}$.

115. Jengel'fel'd V. A. O lesah Zapadnoj Sibiri. 1-e prilozhenie $k$ «Lesnomu zhurnalu» za 1888 g. [Forests of West Siberia. $1^{\text {st }}$ Addendum to 'Lesnoy Journal', 1888]. Saint-Petersburg: Izd-vo Lesnogo obshhestva, 1888, 71 p.

116. Gordjagin A. Ja. Trudy obshhestva estestvoispytatelej pri Kazanskom universitete [Proceedings of Kazan University Society of Naturalists]. Kazan, 1901, vol. 35, iss. 2, pp. 223-528.

117. Tanfil'ev G. I. Trudy Geologicheskoj chasti kabineta Ego Imperatorskago Velichestva [Proceedings of the Geological Committee of the Cabinet of His Imperial Majesty]. 1902, vol. 5, iss. I, pp. 59-319.

118. Rubchevskij V. N. Lesa i naselenie Zavasjugan'ja (Iz putevyh zametok lesnichego) [Forests and Settlements of the Region Around the Vasyugan (Forester's Travel Notes)]. Tomsk: Tip. Gub. upr., 1909, 70 p.

119. Pamjatnaja knizhka Zapadnoj Sibiri [Memory Book of West Siberia]. Omsk: Kartograficheskoe zavedenie Il'ina, $1882,406 \mathrm{p}$

120. Haritonenkov M. A. Lesovedenie [Forest Studies]. 2012, no. 5, pp. 29-35.

121. Istorija Sibiri s drevnejshih vremen do nashih dnej: v 5 t. T. 3. Sibir'v jepohu kapitalizma [History of Siberia from Ancient Times till Present: 5 volumes. Vol. 3. Siberia During Capitalism]. Ed. by A. P. Okladnikov. Leningrad: Nauka, 1968, 532 p.

122. Krest'janstvo Sibiri v jepohu feodalizma [Peasantry in Siberia in Feudal Times]. Ed. by A. P. Okladnikov. Novosibirsk: Nauka, 1982, 502 p.

123. Krest'janstvo Sibiri v jepohu kapitalizma [Peasantry in Siberia in Feudal Times]. Ed. by L. M. Gorjushkin. Novosibirsk: Nauka, 1983, 400 p. 
124. Shunkov V. I. Ocherki po istorii zemledelija Sibiri (XVII v.) [Notes on the History of Land-Farming in Siberia $\left(17^{\text {th }}\right.$ c.)]. Moscow: Izd-vo AN SSSR, 1956, 432 p.

125. Shennikov A. A. Jetnografija narodov SSSR [Ethnography of USSR Peoples]. Leningrad: Nauka, 1971, pp. 76-93.

126. Zhilina T. N. Zapadnaja Sibir'v Malyj lednikovyj period (1550-1850 gg.): priroda i russkaja kolonizacija: dis. kand. geogr. nauk [West Siberia in Little Ice Ace (1550-1850): Nature and Russian Colonization: Research Thesis]. Tomsk, 2004, $161 \mathrm{p}$.

127. Asalhanov I. A. Sel'skoe hozjajstvo Sibiri konca XIX - nachala XX v. [Agriculture in Siberia in late $19^{\text {th }}-$ early $20^{\text {th }} \mathrm{cc}$. Novosibirsk: Nauka. Sib. otd-nie, 1975, $267 \mathrm{p}$.

128. Vlasova I. V. Zemledel'cheskoe osvoenie Sibiri v konce XVII - nachale XXv. [Land Farming in Siberia in the End of 17th - Beginning of 20th cc.]. Novosibirsk: Nauka, 1985, pp. 19-31.

129. Skalozubov N. L., Grabovskij P. A. Obzor Tobol'skoj gubernii v sel'skohozjajstvennom otnoshenii za 1900 god [Tobolsk Governorate Agriculture in 1900]. Tobolsk: Gubernskaja tipografija, 1901, 52 p.

130. Bochanova G. A. Zemledel'cheskoe osvoenie Sibiri v konce XVII-nachale XX v. [Land Farming in Siberia in the End of 17th - Beginning of 20th cc.]. Novosibirsk: Nauka, 1985, pp. 129-150.

131. Turov S. V. Ural'skij sbornik. Istorija. Kul'tura. Religija [Ural Studies. History. Culture. Religion]. Ekaterinburg: Izd-vo UrGU, 1997, iss. 1, pp. 163-168.

132. V. Je. Lesnoj zhurnal [Forest Journal]. 1887, iss. 5, pp. 606-613.

133. Strogij A. A. Istreblenie lesov v Sibiri i neobhodimost' Sibirskogo lesoohranitel'nogo zakona. (Doklad Vserossijskomu $S^{\prime \prime}$ zzdu lesovladel'cev i lesohozjaev v SPb. dlja obsuzhdenija Lesoohranitel'nogo zakona) [Deforestation in Siberia and the Need for Forest Protection Law. (Report at the National Conference of Forestry Managers in St.Petersburg]. Saint-Petersburg: Tip. SPb. Gradonachal'stva, 1911, 24 p.

134. Krylov G. V. Lesa Zapadnoj Sibiri [Forests of West Siberia]. Moscow: Izd-vo AN SSSR, 1961, 255 p.

135. Il'ina I. S., Lapshina E. I., Lavrenko N. N. Rastitel'nyj pokrov Zapadno-Sibirskoj ravniny [Vegetation Layer of West Siberian Plain]. Novosibirsk: Nauka, 1985, 251 p. 